\title{
PENGARUH PENERAPAN STANDAR AKUNTANSI PEMERINTAH, PEMANFAATAN TEKNOLOGI INFORMASI, KOMPETENSI SUMBER DAYA MANUSIA, PENERAPAN SISTEM PENGENDALIAN INTERN PEMERINTAH, DAN SISTEM AKUNTANSI KEUANGAN DAERAH TERHADAP KUALITAS LAPORAN KEUANGAN PEMERINTAH DAERAH
}

(Studi Empiris Pada SKPD Wilayah Kabupaten Tangerang)

\author{
Rama Ardianto \\ Universitas Multimedia Nusantara \\ rama.ardianto@student.umn.ac.id \\ Chermian Eforis \\ Universitas Multimedia Nusantara \\ chermian@umn.ac.id
}

\begin{abstract}
The purpose of this research was to examine the effect of several factors toward quality of local government's financial statement. The factors consist of governmental accounting standards, utilization of information technology, competencies of human resource, government's internal control system, and local financial accounting system. The samples of this research were the employees at Satuan Kerja Perangkat Daerah (SKPD) or regional work unit in Tangerang regency with several characteristic. The characteristics are, 1) using SIMDA as a financial accounting system and 2) involved during preparation of financial statements. The data used was primary data. This research used questionnaire for collecting data. The sampling technique is non-probability samping which is convenience sampling. The results of this research are: (1) governmental accounting standards has significant effect toward the quality of local government's financial statement, (2) utilization of information technology has significant effect toward the quality of local government's financial statement, (3) competencies of human resource has significant effect toward the quality of local government's financial statement, (4) government's internal control system does not affect toward the quality of local government's financial statement, (5) local financial accounting system does not affect toward the quality of local government's financial statement.
\end{abstract}

Keywords : competition of human resource, governments accounting standards, government's internal control system, local financial accounting system, quality of local government's financial statement, utilization of information technology.

\section{PENDAHULUAN}

\subsection{Latar Belakang}

Pada tahun 2015, seluruh instansi pemerintah baik yang ada di pusat maupun di daerah harus sudah menerapkan Standar Akuntansi Pemerintah (SAP) berbasis akrual (accrual basis). Direktur Jendral 
Pengaruh Penerapan Standar Akuntansi Pemerintah, Pemanfaatan Teknologi Informasi, Kompetensi Sumber Daya Manusia, Penerapan Sistem Pengendalian Intern Pemerintah, dan Sistem Akuntansi Keuangan Daerah Terhadap Kualitas Laporan Keuangan Pemerintah Daerah

Keuangan Daerah, Yuswandi A. Temenggung, menyatakan SAP berbasis akrual yang telah ditandatangani mengharuskan pemerintah pusat dan daerah harus menerapkan SAP per 1 Januari 2015. Dasar hukum penerapan SAP berbasis akrual adalah PP No. $71 / 2010$ tentang SAP, sebagai amanat dari UU No. 17/2003 tentang Keuangan Negara. UU No.17/2013 mengamanatkan instansi pemerintah baik di pusat maupun di daerah diminta untuk menerapkan SAP berbasis akrual. Sedangkan dalam PP No. 71/2010 disebutkan SAP berbasis akrual dilaksanakan empat tahun setelah tahun 2010, yang artinya dilaksanakan pada awal tahun 2015. Sementara itu, beberapa hal yang harus disiapkan terkait dengan penerapan SAP berbasis akrual di daerah, yakni ketersediaan Sumber Daya Manusia (SDM) dan Struktur Organisasi Tata Kerja (SOTK) dari Satuan Kerja Perangkat Daerah (SKPD) dan Pejabat Pengelola Keuangan Daerah (PPKD) (Kemendagri, 2014).

Badan Pemeriksa Keuangan (BPK) dapat memberikan empat jenis opini, yaitu Wajar Tanpa Pengecualian (WTP/unqualified opinion), Wajar Dengan Pengecualian (WDP / Qualified opinion), Tidak Memberikan Pendapat (TMT / Disclaimer opinion) dan Tidak Wajar (TW / Adverse opinion). Kualitas laporan keuangan adalah informasi yang disajikan dalam laporan keuangan dengan karakteristik kualitatif yaitu: relevan, andal, dapat dibandingkan, dan dapat dipahami. Berdasarkan kerangka konseptual akuntansi pemerintahan yang terdapat di Standar Akuntansi Pemerintahan laporan keuangan dikatakan berkualitas apabila terdapat karakteristik kualitatif dalam laporan keuangan. Laporan keuangan yang relevan adalah laporan keuangan yang informasinya memungkinkan pengguna untuk mengevaluasi pencapaian di masa lalu, dapat dijadikan sebagai tolak ukur dalam penyusunan anggaran tahun berikutnya, disajikan tepat waktu, dan lengkap, sehingga dapat mempengaruhi pengguna mengambil keputusan yang lebih berkualitas. Laporan keuangan yang andal adalah laporan keuangan yang disajikan 
secara jujur transaksi yang seharusnya disajikan di dalam laporan keuangan, dapat diuji lebih dari satu kali dengan hasil yang tidak jauh berbeda, dan tidak merugikan atau menguntungkan pihak tertentu. Laporan keuangan dapat dibandingkan yaitu laporan keuangan dapat dibandingkan dengan laporan keuangan pada periode sebelumnya dan dengan entitas lain pada umumnya. Laporan keuangan mudah dipahami adalah laporan keuangan yang dapat dipahami dalam bentuk dan istilah yang sesuai dengan batas pemahaman penggunaannya.

Penerapan standar akuntansi pemerintah adalah penggunaan prinsip-prinsip yang tertera pada standar akuntansi pemerintah dalam menyusun laporan keuangan. Standar Akuntansi Pemerintahan terkait penyajian laporan keuangan menyatakan laporan keuangan merupakan laporan yang terstruktur mengenai posisi keuangan dan transaksi-transaksi yang dilakukan oleh suatu entitas pelaporan yang memungkinkan pengguna untuk mengevaluasi pencapaian sasaran dimasa lalu dan dapat dijadikan sebagai tolak ukur dalam penyusunan anggaran di tahun berikutnya. Pernyataan 01 SAP menyatakan penyajian laporan keuangan harus disajikan secara terstruktur dan juga informasi harus diidentifikasikan secara jelas. Penerapan 01 SAP membuat laporan keuangan dapat dibandingkan dan mudah dipahami, sehingga semakin baik penerapan SAP membuat kualitas laporan keuangan menjadi meningkat. Suwita dan Arnan (2015), Sudirianti dkk (2015), dan Ichlas dkk (2014) telah membuktikan bahwa tingginya penerapan standar akuntansi pemerintahan akan meningkatkan kualitas laporan keuangan.

Nurillah dan Muid (2014) mendefinisikan pemanfaatan teknologi informasi sebagai suatu teknologi yang digunakan untuk mengolah data, termasuk memproses,mendapatkan, menyusun, menyimpan, memanipulasi data dalam berbagai cara untuk menghasilkan informasi yang berkualitas, yaitu informasi yang relevan, akurat dan tepat waktu, yang digunakan untuk keperluan pribadi, bisnis, dan pemerintahan dan merupakan informasi yang strategis 
Pengaruh Penerapan Standar Akuntansi Pemerintah, Pemanfaatan Teknologi Informasi, Kompetensi Sumber Daya Manusia, Penerapan Sistem Pengendalian Intern Pemerintah, dan Sistem Akuntansi Keuangan Daerah Terhadap Kualitas Laporan Keuangan

Pemerintah Daerah

untuk pengambilan keputusan.

Pemanfaatan teknologi informasi adalah penggunaan teknologi informasi yaitu komputer dan jaringan internet dalam mengolah data dan menghasilkan informasi yang berkualitas. Dengan adanya pemanfaatan teknologi informasi proses akuntansi yang sebelumnya dilakukan secara manual dapat dilakukan secara komputerisasi agar dapat mempercepat penyusunan laporan keuangan dan juga komputerisasi yang didukung dengan pengunaan aplikasi (software) dapat meminimalisir kesalahan pencatatan. Ketika kesalahan pencatatan dapat diminimalisir dan penyajian laporan keuangan dapat lebih dipercepat membuat laporan keuangan semakin andal dan relevan sehingga semakin baik pemanfaatan teknologi informasi, kualitas laporan keuangan semakin meningkat. Nurillah dan Muid (2014) dan Yosefrinaldi (2013) telah membuktikan bahwa pemanfaatan teknologi informasi berpengaruh secara positif dan signifikan terhadap kualitas laporan keuangan pemerintah daerah.
Menurut Yensi (2014) kompetensi SDM adalah kemampuan dan karakteristik yang dimiliki oleh seseorang berupa pengetahuan, keterampilan, dan sikap perilaku yang diperlukan dalam tugasnya. SDM yang berkompeten dapat bertanggung jawab atas tugas yang dikelolanya akan menyusun laporan keuangan sesuai dengan pedoman akuntansi yang berlaku secara lengkap dan wajar dan membuat laporan keuangan relevan dan andal, sehingga semakin baik kompetensi SDM, kualitas laporan keuangan semakin meningkat. Nurillah dan Muid (2014) dan Hadiputro dan Octavia (2015) telah membuktikan bahwa kompetensi sumber daya manusia berpengaruh positif terhadap kualitas laporan keuangan.

Penerapan sistem pengendalian intern pemerintah yaitu penggunaan peraturan pemerintah No. 60 tahun 2008 dalam instansi pemerintah untuk dijadikan pedoman dalam menerapkan kode etik dan melakukan penilaian risiko untuk mengendalikan lingkungan internal. Dalam pernyataan lingkungan pengendalian, instansi pemerintah 
akan meningkatkan kedisiplinan karyawan dengan menerapkan kode etik secara tertulis dalam menyusun laporan keuangan sesuai dengan peraturan yang berlaku dan dengan transaksi - transaksi yang benar terjadi sehingga informasi dalam laporan keuangan menggambarkan secara jujur/wajar dan membuat laporan keuangan menjadi relevan dan andal sehingga semakin baik penerapan SPIP maka kualitas laporan keuangan pemerintah daerah semakin meningkat. Evicahyani dan Setiawina (2016) dan Nurillah dan Muid (2014) telah membuktikan bahwa penerapan Sistem Pengendalian Intern Pemerintah (SPIP) berpengaruh secara positif dan signifikan terhadap kualitas laporan keuangan.

Sistem Akuntansi Keuangan Daerah adalah serangkaian prosedur mulai dari proses pengumpulan data, pencatatan, pengikhtisaran, sampai dengan pelaporan keuangan dalam rangka pertanggungjawaban pelaksanaan Anggaran Pendapatan dan Belanja Daerah (APBD) yang ditujukan untuk menghasilkan informasi berupa laporan keuangan yang dapat dilakukan secara manual atau menggunakan aplikasi komputer (Nordiawan, 2010). Sistem Akuntansi Keuangan Daerah dalam penelitian ini menggunakan aplikasi komputer yaitu Sistem Informasi Manajemen Daerah (SIMDA) yang diciptakan oleh Badan Pengawasan Keuangan dan Pembangunan (BPKP). Sistem akuntansi keuangan daerah dapat menyajikan laporan keuangan sesuai dengan Peraturan Pemerintah No. 71 tahun 2010 secara lengkap dan membuat laporan keuangan menjadi relevan dan dapat dibandingkan secara internal maupun eksternal sehingga semakin baik sistem akuntansi keuangan daerah maka kualitas laporan keuangan semakin meningkat. Nurillah dan Muid (2014) telah membuktikan bahwa Sistem Akuntansi Keuangan Daerah (SAKD) berpengaruh secara positif dan signifikan terhadap kualitas laporan keuangan pemerintah daerah.

\subsection{Rumusan Masalah}

Berdasarkan latar belakang masalah dan pembatasan masalah yang telah diuraikan, maka perumusan masalah yang akan dibahas dalam penelitian ini adalah sebagai berikut: 
Pengaruh Penerapan Standar Akuntansi Pemerintah, Pemanfaatan Teknologi Informasi, Kompetensi Sumber Daya Manusia, Penerapan Sistem Pengendalian Intern Pemerintah, dan Sistem Akuntansi Keuangan Daerah Terhadap Kualitas Laporan Keuangan Pemerintah Daerah

1. Apakah penerapan standar akuntansi pemerintah berpengaruh terhadap kualitas laporan keuangan pemerintah daerah?

2. Apakah pemanfaatan teknologi informasi berpengaruh terhadap kualitas laporan keuangan pemerintah daerah?

3. Apakah kompetensi sumber daya manusia berpengaruh terhadap kualitas laporan keuangan pemerintah daerah?

4. Apakah penerapan sistem pengendalian intern pemerintah berpengaruh terhadap kualitas laporan keuangan pemerintah daerah?

5. Apakah sistem akuntansi keuangan daerah berpengaruh terhadap kualitas laporan keuangan pemerintah daerah?

\subsection{Tujuan Penelitian}

Penelitian ini bertujuan untuk memperoleh bukti empiris mengenai:

1. Pengaruh penerapan standar akuntansi pemerintah terhadap kualitas laporan keuangan pemerintah daerah.

2. Pengaruh pemanfaatan teknologi informasi terhadap kualitas

laporan keuangan pemerintah daerah.

3. Pengaruh kompetensi sumber daya manusia terhadap kualitas laporan keuangan pemerintah daerah.

4. Pengaruh penerapan sistem pengendalian intern pemerintah terhadap kualitas laporan keuangan pemerintah daerah.

5. Pengaruh sistem akuntansi keuangan daerah terhadap kualitas laporan keuangan pemerintah daerah.

\section{TELAAH LITERATUR}

\subsection{Pemerintah Daerah}

Menurut PP No. 41 Tahun 2007, pemerintah daerah adalah gubernur, bupati atau walikota, dan perangkat daerah sebagai unsur penyelenggara pemerintah daerah. Dalam UndangUndang Dasar Negara Republik Indonesia (NKRI) pemerintah daerah adalah penyelenggara urusan pemerintahan oleh pemerintah daerah dan DPRD menurut asas otonomi dan tugas pembantuan dengan prinsip ekonomi seluasluasnya dalam sistem dan prinsip 
Negara Kesatuan Republik Indonesia (NKRI).

Menurut Nordiawan dan Hertianti (2010), pada tingkat provinsi, struktur pemerintah daerah terdiri atas beberapa organisasi perangkat daerah, perangkat daerah sendiri menurut PP No. 16 Tahun 2016 tentang perangkat daerah adalah unsur pembantu kepala daerah dan Dewan Perwakilan Rakyat Daerah dalam penyelenggaraan urusan pemerintah yang menjadi kewenangan daerah. Menurut Kementrian Keuangan (2015), Satuan Kerja Perangkat Daerah adalah organisasi/lembaga pada pemerintah daerah yang bertanggungjawab kepada gubernur/bupati/walikota dalam pengembangan sistem aplikasi keuangan tingkat instansi dan aplikasi pendukungnya dalam rangka mendukung Sistem Perbendaharaan dan Anggaran Negara (SPAN) rangka penyelenggaran pemerintahan.

\subsection{Laporan Keuangan}

\section{Pemerintah Daerah}

Sebagai bentuk pertanggungjawaban ke masyarakat, pemerintah meningkatkan akuntabilitas publik dengan menyajikan laporan keuangan. Akuntabilitas dapat diartikan sebagai bentuk kewajiban mempertanggungjawabkan

keberhasilan atau kegagalan pelaksanaan misi organisasi dalam mencapai tujuan dan sasaran yang telah ditetapkan sebelumnya melalui media pertanggungjawaban yang dilaksanakan secara periodik (Stanbury, 2003 dalam Juwita, 2013).

Menurut PP No. 71 Tahun 2010, entitas pelaporan merupakan unit pemerintahan yang terdiri dari satu atau lebih entitas akuntansi yang menurut ketentuan peraturan perundang-undangan wajib menyajikan laporan pertanggungjawaban berupa laporan keuangan. Kerangka konseptual akuntansi pemerintahan pada bagian peranan laporan keuangan yang terdapat di dalam standar akuntansi pemerintahan, menyatakan: "laporan keuangan disusun untuk menyediakan informasi keuangan yang relevan mengenai posisi keuangan dan seluruh transaksi yang dilakukan oleh suatu entitas pelaporan selama satu periode 
Pengaruh Penerapan Standar Akuntansi Pemerintah, Pemanfaatan Teknologi Informasi, Kompetensi Sumber Daya Manusia, Penerapan Sistem Pengendalian Intern Pemerintah, dan Sistem Akuntansi Keuangan Daerah Terhadap Kualitas Laporan Keuangan Pemerintah Daerah

pelaporan. Laporan keuangan terutama digunakan untuk mengetahui nilai sumber daya ekonomi yang dimanfaatkan untuk melaksanakan kegiatan operasional pemerintahan, menilai kondisi keuangan, mengevaluasi efektivitas dan efisiensi suatu entitas pelaporan, dan membantu menentukan ketaatannya terhadap peraturan perundang-undangan”. (Komite Standar Akuntansi Pemerintahan, 2010, para. 24)

\subsection{Kualitas Laporan Keuangan Pemerintah Daerah}

Peraturan Pemerintah No. 71 Tahun 2010 menentukan beberapa karakteristik kualitatif pelaporan keuangan sebagaimana disyaratkan dalam Standar Akuntansi Pemerintah (SAP) tahun 2010 yaitu:

1. Relevan

$\begin{array}{lcr}\begin{array}{l}\text { Laporan } \\ \text { dikatakan }\end{array} & \begin{array}{l}\text { keuangan } \\ \text { relevan }\end{array} & \begin{array}{r}\text { bisa } \\ \text { apabila }\end{array} \\ \text { informasi } & \text { yang } & \text { termuat } \\ \text { didalamnya } & \text { dapat } \\ \text { mempengaruhi } & \text { keputusan } \\ \text { pengguna dengan } & \text { membantu } \\ \text { pengguna } & \text { mengevaluasi } \\ \text { peristiwa masa lalu atau masa }\end{array}$

kini dan memprediksi masa depan, serta menegaskan atau mengoreksi hasil evaluasi di masa lalu. Dengan demikian informasi laporan keuangan yang relevan dapat dihubungkan dengan maksud penggunanya.

Informasi yang relevan memenuhi karakteristik berikut ini:

a. Memiliki manfaat umpan balik (feedback value) Informasi memungkinkan pengguna untuk menegaskan atau mengoreksi

ekspektasi pengguna di masa lalu.

b. Memiliki manfaat prediktif (predictive value)

Informasi dapat membantu pengguna untuk memprediksi masa yang akan datang berdasarkan hasil dari masa lalu dan kejadian masa kini.

c. Tepat waktu

Informasi disajikan tepat waktu sehingga dapat berpengaruh dan berguna 


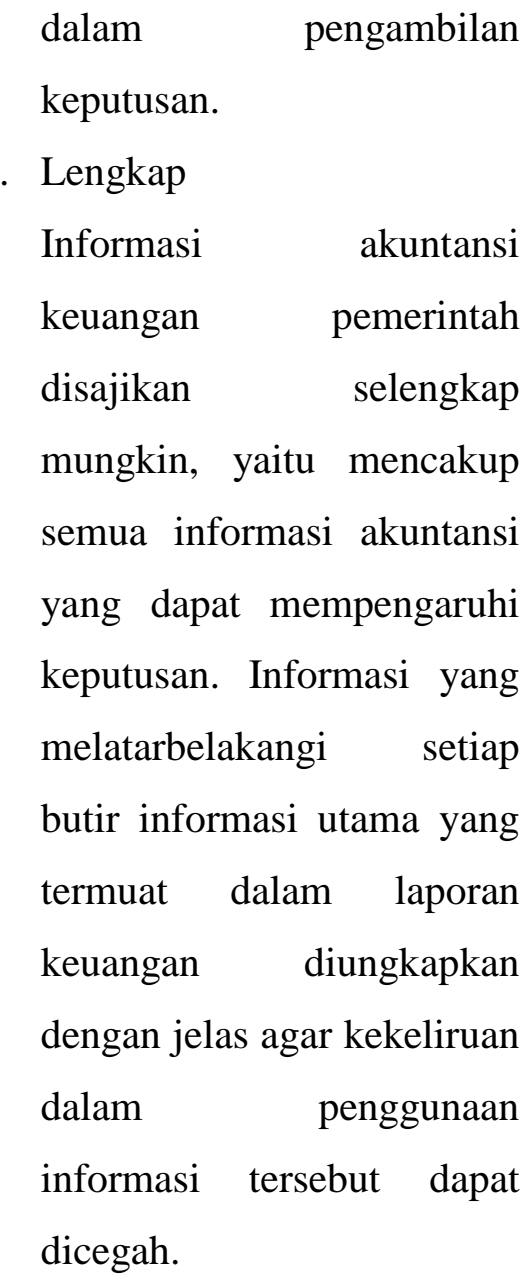

2. Andal

Informasi yang terkandung
dalam laporan keuangan
terbebas dari pengertian yang
menyesatkan dan kesalahan
material, menyajikan setiap
fakta secara jujur, serta dapat
diverifikasi. Informasi mungkin
relevan, tetapi jika hakikat atau
penyajiannya tidak dapat
diandalkan, maka penggunaan
informasi tersebut secara
potensial dapat menyesatkan.

Informasi yang andal memenuhi karakteristik berikut ini:

a. Penyajian Jujur Informasi menggambarkan dengan jujur transaksi serta peristiwa lainnya yang seharusnya disajikan atau yang secara wajar dapat diharapkan untuk disajikan.

b. Dapat diverifikasi (verifiability)

Informasi yang disajikan dalam laporan keuangan dapat diuji dan apabila pengujian dilakukan lebih dari sekali oleh pihak yang berbeda, hasilnya tetap menunjukkan simpulan yang tidak berbeda jauh.

c. Netralitas

Informasi diarahkan pada kebutuhan umum dan tidak berpihak pada kebutuhan pihak tertentu.

3. Dapat dibandingkan

Informasi yang termuat dalam laporan keuangan akan lebih berguna jika dapat dibandingkan dengan laporan keuangan periode sebelumnya atau laporan keuangan entitas pelaporan lain pada umumnya. Perbandingan 
Pengaruh Penerapan Standar Akuntansi Pemerintah, Pemanfaatan Teknologi Informasi, Kompetensi Sumber Daya Manusia, Penerapan Sistem Pengendalian Intern Pemerintah, dan Sistem Akuntansi Keuangan Daerah Terhadap Kualitas Laporan Keuangan Pemerintah Daerah

dapat dilakukan secara internal dan eksternal. Perbandingan secara internal dapat dilakukan bila suatu entitas menerapkan kebijakan akuntansi yang sama dari tahun ke tahun. Perbandingan secara eksternal dapat dilakukan bila entitas yang diperbandingkan menerapkan kebijakan akuntansi yang sama. Apabila entitas pemerintah menerapkan kebijakan akuntansi yang lebih baik daripada kebijakan akuntansi yang sekarang diterapkan, perubahan tersebut diungkapkan pada periode terjadinya perubahan.

4. Dapat dipahami

Informasi yang disajikan dalam laporan keuangan dapat dipahami oleh pengguna dan dinyatakan dalam bentuk serta istilah yang disesuaikan dengan batas pemahaman para pengguna. Untuk itu, pengguna diasumsikan memiliki pengetahuan yang memadai atas kegiatan dan lingkungan operasi entitas pelaporan, serta adanya kemauan pengguna untuk mempelajari informasi yang dimaksud.

\subsection{Penerapan Standar Akuntansi} Pemerintah

\begin{tabular}{lcr} 
Penerapan & \multicolumn{1}{c}{ standar } & akuntansi \\
pemerintah & (PSAP) & adalah \\
penggunaan & \multicolumn{2}{c}{ prinsip-prinsip } \\
akuntansi & pemerintah & dalam \\
menyusun & laporan & keuangan \\
pemerintah & daerah. & terdapat 12 \\
penerapan & standar & akuntansi
\end{tabular}

a. PSAP No. 1 tentang penyajian laporan keuangan Tujuan dari PSAP ini adalah mengatur penyajian laporan keuangan untuk tujuan umum dalam rangka meningkatkan keterbandingan laporan keuangan baik terhadap anggaran, antar periode, maupun antar entitas.

b. PSAP No. 2 tentang laporan realisasi anggaran Tujuan pelaporan realisasi anggaran adalah memberikan informasi realisasi dan anggaran entitas pelaporan. Perbandingan antara anggaran dan realisasinya 


$\begin{array}{lrl}\text { menunjukkan } & \text { tingkat } & \text { dianggap perlu disajikan } \\ \text { ketercapaian } & \text { target-target } & \text { dalam laporan keuangan. }\end{array}$

yang telah disepakati antara legislatif dan eksekutif sesuai dengan peraturan perundangundangan.

c. PSAP No. 3 tentang laporan arus kas

f. PSAP No. 6 tentang akuntansi investasi

Tujuan dari PSAP ini adalah untuk mengatur perlakuan akuntansi untuk investasi dan pengungkapan informasi Tujuan pelaporan arus kas adalah memberikan informasi mengenai sumber, penggunaan, perubahan kas dan setara kas selama suatu periode akuntansi serta saldo kas dan setara kas pada tanggal pelaporan.

d. PSAP No. 4 tentang catatan atas laporan keuangan Tujuan penyajian catatan atas laporan keuangan adalah untuk meningkatkan transparansi laporan keuangan dan penyediaan pemahaman yang lebih baik, atas informasi keuangan pemerintah.

e. PSAP No. 5 tentang akuntansi persediaan tujuan dari PSAP ini adalah untuk mengatur perlakuan akuntansi persediaan yang penting lainnya yang harus disajikan dalam laporan keuangan.

g. PSAP No. 7 tentang akuntansi aset tetap

Tujuan PSAP ini adalah mengatur perlakuan akuntansi untuk aset tetap meliputi pengakuan, penentuan nilai tercatat, serta penentuan dan perlakuan akuntansi atas penilaian kembali dan penurunan nilai tercatat (carrying value) aset tetap.

h. PSAP No. 8 tentang akuntansi konstruksi dalam pengerjaan

Tujuan dari PSAP ini adalah mengatur perlakuan akuntansi untuk konstruksi dalam pengerjaan.

i. PSAP No. 9 tentang akuntansi kewajiban 
Pengaruh Penerapan Standar Akuntansi Pemerintah, Pemanfaatan Teknologi Informasi, Kompetensi Sumber Daya Manusia, Penerapan Sistem Pengendalian Intern Pemerintah, dan Sistem Akuntansi Keuangan Daerah Terhadap Kualitas Laporan Keuangan Pemerintah Daerah

Tujuan PSAP ini adalah mengatur perlakukan akuntansi kewajiban meliputi saat pengakuan, penentuan nilai tercatat, amortisasi, dan biaya pinjaman yang dibebankan terhadap kewajiban tersebut.

j. PSAP No. 10 tentang koreksi kesalahan, perubahan kebijakan akuntansi, perubahan estimasi akuntansi dan operasi yang tidak dilanjutkan

Tujuan dari PSAP ini adalah mengatur perlakuan akuntansi atas koreksi kesalahan akuntansi dan pelaporan laporan keuangan, perubahan kebijakan akuntansi, perubahan estimasi akuntansi, dan operasi yang tidak dilanjutkan. Dalam mengoreksi suatu kesalahan akuntansi, jumlah koreksi yang berhubungan dengan periode sebelumnya harus dilaporkan dengan menyesuaikan baik saldo anggaran lebih maupun saldo ekuitas. k. PSAP No. 11 tentang laporan keuangan konsolidasian tujuan dari PSAP ini adalah mengatur penyusunan laporan keuangan konsolidasian pada unit-unit pemerintahan dalam rangka menyajikan laporan keuangan untuk tujuan umum (general purpose financial statements) demi meningkatkan kualitas dan kelengkapan laporan keuangan dimaksud.

1. PSAP No. 12 tentang laporan operasional

tujuan pelaporan PSAP ini adalah memberikan informasi tentang kegiatan operasional keuangan yang tercerminkan dalam pendapatan-LO, beban, dan surplus/deficit operasional dari suatu entitas pelaporan.

Berdasarkan teori yang telah diuraikan, maka hipotesis yang diajukan adalah sebagai berikut:

$\mathrm{Ha}_{1}$ : Penerapan standar akuntansi pemerintahan berpengaruh terhadap kualitas laporan keuangan pemerintah daerah. 
2.5 Pemanfaatan Teknologi Informasi

Dalam penjelasan Peraturan Pemerintah No. 56 Tahun 2005 tentang Sistem Informasi Keuangan Daerah disebutkan bahwa untuk menindaklanjuti terselenggaranya proses pembangunan yang sejalan dengan prinsip tata kelola pemerintahan yang baik (Good Governance), pemerintah, dan pemerintah daerah berkewajiban untuk mengembangkan dan memanfaatkan kemajuan teknologi informasi untuk meningkatkan kemampuan mengelola keuangan daerah, dan menyalurkan informasi keuangan daerah kepada pelayanan publik. Pemerintah perlu mengoptimalisasi pemanfaatan kemajuan teknologi informasi untuk membangun jaringan sistem informasi manajemen dan proses kerja yang memungkinkan pemerintahan bekerja secara terpadu dengan menyederhanakan akses antar unit kerja (Nurillah dan Muid 2014). Berdasarkan teori yang telah diuraikan, maka hipotesis yang diajukan adalah sebagai berikut:

$$
\begin{array}{crr}
\mathrm{Ha}_{2} \text { : } & \text { Pemanfaatan } & \text { teknologi } \\
& \text { informasi } & \text { berpengaruh }
\end{array}
$$

terhadap kualitas laporan keuangan pemerintah daerah.

\subsection{Kompetensi Sumber Daya Manusia}

Menurut Hevesi, (2005) dalam Indriasari dan Ertambang Nahartyo (2008), dalam Soimah. (2014) kompetensi merupakan suatu karakteristik dari seseorang yang memiliki keterampilan (skill), pengetahuan (knowledge) dan kemampuan (ability) untuk melaksanakan suatu pekerjaan. Menurut Yensi (2014) kompetensi SDM adalah kemampuan dan karakteristik yang dimiliki oleh seseorang berupa pengetahuan, keterampilan, dan sikap perilaku yang diperlukan dalam tugasnya. Menurut Widodo (2001) dalam Evicahyani dan Setiawan (2016) Kompetensi SDM adalah kemampuan SDM untuk melaksanakan tugas dan tanggung jawab yang diberikan kepadanya dengan bekal pendidikan, pelatihan, dan pengalaman yang cukup memadai. SDM yang berkompeten akan mampu memahami logika akuntansi dengan baik . 
Pengaruh Penerapan Standar Akuntansi Pemerintah, Pemanfaatan Teknologi Informasi, Kompetensi Sumber Daya Manusia, Penerapan Sistem Pengendalian Intern Pemerintah, dan Sistem Akuntansi Keuangan Daerah Terhadap Kualitas Laporan Keuangan Pemerintah Daerah

Menurut UU. No. 23 Tahun 2011, untuk mengetahui kompetensi yang dimiliki Pegawai Negeri Sipil (PNS) sesuai dengan yang dipersyaratkan perlu dilakukan penilaian kompetensi PNS. Penilaian Kompetensi adalah suatu proses membandingkan antara kompetensi jabatan yang dipersyaratkan dengan kompetensi yang dimiliki oleh pemegang jabatan atau calon pemegang jabatan. Alat ukur kompetensi PNS dalam UU No.

23 Tahun 2011 yaitu: psikotes, wawancara kompetensi, kuesioner kompetensi, dan simulasi. Menurut Alimbudiono \& Fidelis (2004) dalam Indriasari \& Nahartyo (2008) dalam Soimah (2014), tanggung jawab dapat dilihat dari atau tertuang pada deskripsi jabatan. Deskripsi jabatan merupakan dasar untuk melaksanakan tugas dengan baik. Tanpa adanya deskripsi jabatan yang jelas, sumberdaya tersebut tidak dapat melaksanakan tugasnya. Menurut Griffin (2004) dalam Delanno \& Deviani (2013) sumber daya manusia dapat diukur melalui rata-rata pendidikan, pelatihan dan tingkat pengalaman. Pendidikan merupakan suatu kegiatan yang universal dalam kehidupan manusia. Pelatihan adalah proses sistematis mengubah tingkah laku seseoran untuk mencapai tujuan organisasi. Pelatihan yang baik, harus berkaitan dengan keahlian dan kemampuan untuk melaksanakan pekerjaannya. Pengalaman dilihat dari lamanya seorang bekerja. Dengan pengalaman, seseorang akan terbiasa melakukan suatu pekerjaan dan mempunyai wawasan yang luas serta mudah beradaptasi dengan lingkungan. Berdasarkan teori yang telah diuraikan, maka hipotesis yang diajukan adalah sebagai berikut:

$\mathrm{Ha}_{3}$ : Kompetensi sumber daya manusia berpengaruh terhadap kualitas laporan keuangan pemerintah daerah.

\subsection{Penerapan Sistem Pengendalian Intern}

\section{Pemerintah}

Menurut PP No. 60 Tahun 2008, definisi Sistem Pengendalian Intern Pemerintah (SPIP) adalah suatu proses secara integral pada tindakan dan kegiatan yang dilakukan secara terus-menerus oleh pimpinan dan seluruh pegawai untuk memberikan 
keyakinan memadai atas tercapainya tujuan organisasi melalui kegiatan yang efektif dan efisien. Menurut Rai (2008) dalam Herawati (2014), sistem pengendalian intern adalah kebijakan dan prosedur yang dirancang untuk memberikan keyakinan yang memadai bagi manajemen bahwa organisasi mencapai tujuan dan sasarannya. Penerapan sistem pengendalian intern pemerintah adalah penerapan PP No. 60 tahun 2008 kepada seluruh pegawai yang bekerja di instansi pemerintahan. Salah satu upaya untuk mewujudkan penyelenggaraan administrasi pemerintah yang pasti dan menghindari berbagai bentuk penyimpangan yaitu dibentuknya Standard Operating Procedurs (SOP). Menurut Permenpan No. 21 Tahun 2008, SOP adalah serangkaian instruksi tertulis yang dibakukan mengenai berbagai proses penyelenggaraan administrasi pemerintahan, bagaimana dan kapan harus dilakukan, serta dimana dan oleh siapa dilakukan. Berdasarkan teori yang telah diuraikan, maka hipotesis yang diajukan adalah sebagai berikut:
$\mathrm{Ha}_{4}$ : Penerapan sistem pengendalian intern pemerintah berpengaruh terhadap kualitas laporan keuangan pemerintah daerah.

\subsection{Sistem Akuntansi Keuangan Daerah}

Sistem Akuntansi Keuangan Daerah adalah serangkaian prosedur mulai dari proses pengumpulan data, pencatatan, pengikhtisaran, sampai dengan pelaporan keuangan dalam rangka pertanggungjawaban pelaksanaan Anggaran Pendapatan dan Belanja Daerah (APBD) yang ditujukan untuk menghasilkan informasi berupa laporan keuangan yang dapat dilakukan secara manual atau menggunakan aplikasi komputer (Nordiawan, 2010). Sistem Akuntansi Keuangan Daerah dalam penelitian ini menggunakan aplikasi komputer yaitu Sistem Informasi Manajemen Daerah (SIMDA) yang diciptakan oleh Badan Pengawasan Keuangan dan Pembangunan (BPKP). Penerapan sistem informasi akuntansi pada pemerintah daerah diatur dalam Peraturan Menteri Dalam Negeri No. 13 Tahun 2006 tentang pedoman pengelolaan keuangan daerah. BPKP dalam hal 
Pengaruh Penerapan Standar Akuntansi Pemerintah, Pemanfaatan Teknologi Informasi, Kompetensi Sumber Daya Manusia, Penerapan Sistem Pengendalian Intern Pemerintah, dan Sistem Akuntansi Keuangan Daerah Terhadap Kualitas Laporan Keuangan Pemerintah Daerah

ini memberikan respon positif pertanggungjawabannya, dan juga dengan mengembangkan sebuah prosedur pengelolaan keuangan program aplikasi komputer yang seperti yang telah dijelaskan dalam dinamakan SIMDA. Menurut Peraturan Menteri Dalam Negeri No. Nugraha dan Astuti (2013) BPKP melakukan pengembangan aplikasi SIMDA dengan tujuan mendukung tercapainya akuntabilitas bagi pemerintah daerah, aplikasi ini diharapkan dapat membantu pemerintah daerah dalam penyusunan perencanaan dan penganggaran, serta pelaksanaan dan penatausahaan Anggaran Pendapatan 13 Tahun 2006 telah diimplementasikan dengan cukup baik oleh aplikasi SIMDA. Berdasarkan uraian tersebut, maka dapat diambil hipotesis sebagai berikut:

$\begin{aligned} \text { Ha}_{5}: & \text { Sistem akuntansi keuangan } \\ & \text { daerah berpengaruh terhadap } \\ & \text { kualitas laporan keuangan } \\ & \text { pemerintah daerah. }\end{aligned}$

dan Belanja Daerah dan

\subsection{Model Penelitian}

Berikut adalah gambar dari model penelitian ini:

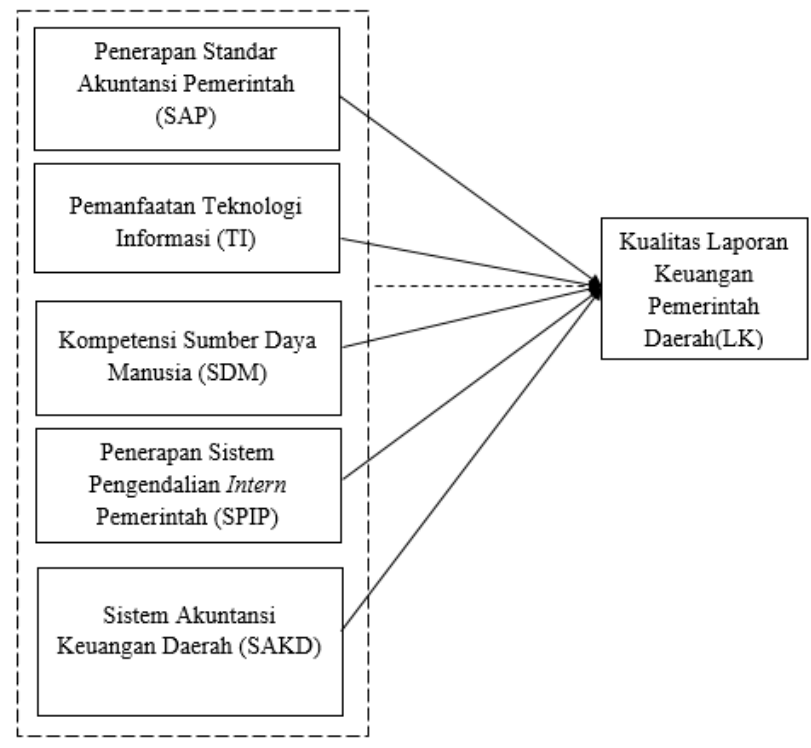

Gambar 1. Model Penelitian 
3. METODOLOGI PENELITIAN

\subsection{Gambaran Umum Objek} Penelitian

Satuan Kerja Perangkat Daerah (SKPD) wilayah Tangerang yang difasilitasi dengan komputer dan sistem akuntansi keuangan daerah. Responden yang digunakan untuk penelitian adalah pegawai terlibat langsung dalam penyusunan laporan keuangan dan menggunakan sistem akuntansi keuangan daerah.

\subsection{Metode Penelitian}

Penelitian ini merupakan penelitian hubungan sebab akibat (causal study). Studi yang menggambarkan hubungan sebab akibat dari satu atau lebih masalah dalam penelitian (Sekaran, 2016).

\subsection{Variabel Penelitian}

\subsubsection{Variabel dependen}

Variabel dependen yang digunakan dalam penelitian ini adalah kualitas laporan keuangan pemerintah daerah (LK). Kualitas laporan keuangan adalah informasiinformasi yang tertera pada laporan keuangan yang memenuhi karakteristik kualitatif. Laporan keuangan yang berkualitas berarti laporan tersebut memenuhi karakteristik kualitatif laporan keuangan pada PP No. 71 Tahun 2010 yaitu informasi dalam laporan keuangan harus relevan, andal, dapat dibandingkan, dan dapat dipahami.

Kuesioner untuk mengukur variabel kualitas laporan keuangan pemerintah daerah dalam penelitian ini mengacu pada penelitian Dewi dan Mimba (2014). Indikator untuk variabel ini terdiri dari 11 pernyataan positif yaitu: 4 buah pernyataan mengenai relevansi laporan keuangan, 3 buah mengenai keandalan laporan keuangan, 2 buah mengenai dapat dibandingkanya laporan keuangan, dan 2 buah mengenai dapat dipahaminya laporan keuangan. Variabel dependen dalam penelitian ini diukur dengan skala interval yaitu menggunakan skala Likert untuk 5 preferensi jawaban sebagai berikut: 1 : 
Pengaruh Penerapan Standar Akuntansi Pemerintah, Pemanfaatan Teknologi Informasi, Kompetensi Sumber Daya Manusia, Penerapan Sistem Pengendalian Intern Pemerintah, dan Sistem Akuntansi Keuangan Daerah Terhadap Kualitas Laporan Keuangan Pemerintah Daerah

Sangat Tidak Setuju (STS);

2: Tidak Setuju (TS); 3: Kurang Setuju (KS); 4: Setuju (S); 5: Sangat Setuju (SS)

\subsubsection{Variabel Independen}

Variabel independen adalah variabel yang dapat memengaruhi variabel dependen baik secara positif maupun negatif (Sekaran dan Bougie, 2016).

\section{Penerapan Standar Akuntansi Pemerintah}

Penerapan standar akuntansi pemerintah adalah penggunaan prinsip-prinsip akuntansi dalam menyusun laporan keuangan pemerintah daerah. Standar Akuntansi Pemerintahan (SAP) adalah prinsip-prinsip akuntansi yang diterapkan dalam menyusun dan menyajikan laporan keuangan pemerintah. Dalam SAP sendiri terdapat kerangka konseptual akuntansi pemerintahan serta 12 pernyataan yaitu penyajian laporan keuangan, laporan realisasi anggaran, laporan arus kas, catatan atas laporan keuangan, akuntansi persediaan, akuntansi investasi, akuntansi aset tetap, akuntansi konstruksi dalam pengerjaan, akuntansi kewajiban, koreksi kesalahan, perubahan kebijakan akuntansi, perubahan estimasi akuntasi, operasi yang tidak dilanjutkan, laporan keuangan konsolidasian, dan laporan keuangan operasional. Dalam penelitian ini variabel penerapan Standar Akuntansi Pemerintahan diukur menggunakan kuesioner yang mengacu pada penelitian Suwita dan Arnan (2015). Indikator untuk variabel ini terdiri dari 27 pernyataan positif yang diukur dengan skala interval yaitu menggunakan skala Likert dengan jawaban: 1: Sangat Tidak Setuju (STS); 2: Tidak Setuju (TS); 3: Kurang Setuju (KS); 4: Setuju (S); 5: Sangat Setuju (SS); yang dijabarkan sebagai berikut:

a. 4 buah pernyataan Penyajian Laporan Keuangan.

b. 2 buah pernyataan Laporan Realisasi Anggaran.

c. 4 buah pernyataan Laporan Arus Kas.

d. 1 buah pernyataan Catatan atas Laporan Keuangan.

e. 2 buah pernyataan Akuntansi Persediaan. 
f. 1 buah pernyataan Akuntansi Investasi.

g. 2 buah pernyataan Akuntansi Aset Tetap.

h. 1 buah pernyataan Akuntansi Konstruksi Dalam Pengerjaan.

i. 2 buah pernyataan Akuntansi Kewajiban.

j. 4 buah pernyataan Koreksi Kesalahan, Perubahan Kebijakan Akuntansi, Perubahan Estimasi Akuntansi dan Peristiwa Luar Biasa.

k. 1 buah pernyataan Laporan Keuangan Konsolidasian.

1. 2 buah pernyataan Laporan Operasional.

\section{Pemanfaatan Teknologi Informasi}

Pemanfaatan teknologi informasi adalah penggunaan teknologi informasi yaitu komputer dan jaringan internet dalam mengolah data dan menghasilkan informasi yang berkualitas. Besarnya pemanfaatan atau kontribusi teknologi informasi dalam penyusunan laporan keuangan dapat dilihat dengan seberapa sering pegawai atau karyawan kantor pemerintahan menggunakan fasilitas komputer dan internet yang diberikan secara maksimal dalam mengolah data keuangan yang akan disusun menjadi sebuah laporan keuangan. Pemanfaatan teknologi informasi lebih maksimal apabila sarana (komputer) yang digunakan untuk menyusun laporan keuangan dipelihara dan dirawat secara teratur. Dalam penelitian ini variabel pemanfaatan teknologi informasi diukur menggunakan kuesioner yang mengacu pada penelitian Soimah dan Aprilla (2014). Indikator untuk variabel ini terdiri dari 7 buah pernyataan positif yaitu: 6 buah pernyataan mengenai pemanfaatan komputer dan 1 buah pernyataan mengenai pemanfaatan internet. Variabel ini diukur dengan skala interval yaitu menggunakan skala Likert untuk 5 preferensi jawaban sebagai berikut: 1: Tidak Pernah (TP); 2: Jarang Sekali (JS); 3: Kadang-Kadang (KK); 4: Sering (S); 5: Sangat Sering (SS).

\section{Kompetensi Sumber Daya Manusia}

Kompetensi sumber daya manusia adalah kemampuan seseorang dalam menjalankan tugas sesuai dengan 
Pengaruh Penerapan Standar Akuntansi Pemerintah, Pemanfaatan Teknologi Informasi, Kompetensi Sumber Daya Manusia, Penerapan Sistem Pengendalian Intern Pemerintah, dan Sistem Akuntansi Keuangan Daerah Terhadap Kualitas Laporan Keuangan Pemerintah Daerah

pedoman yang diberikan berdasarkan pengalaman dan pelatihan yang sudah diterima. Sumber daya manusia yang kompeten dalam penyusunan laporan keuangan yaitu karyawan bertanggung jawab dalam melaksanakan tugas pengelolaan keuangan yang diberikan sesuai dengan pedoman akuntansi yang ada dan memiliki pengetahuan serta pengalaman dalam bidang akuntansi yang memadai. Kompetensi SDM dapat didukung oleh pelatihanpelatihan dalam bidang akuntansi yang diberikan oleh kantor. Dalam penelitian ini variabel kompetensi sumber daya manusia diukur menggunakan kuesioner yang mengacu pada penelitian Soimah dan Aprilla (2014). Indikator untuk variabel ini terdiri dari 8 buah pernyataan positif yaitu: 3 buah pernyataan mengenai tanggungjawab, 3 pernyataan mengenai pelatihan, dan 2 pernyataan mengenai pengalaman. Variabel ini diukur dengan skala interval yaitu menggunakan skala Likert untuk 5 preferensi jawaban sebagai berikut: 1: Sangat Tidak Setuju (STS); 2: Tidak Setuju (TS);
3: Netral (N); 4: Setuju (S); 5: Sangat Setuju (SS).

\section{Penerapan Sistem Pengendalian Intern Pemerintah}

Penerapan sistem pengendalian intern pemerintah adalah penggunaan peraturan pemerintah No. 60 tahun 2008 dalam instansi pemerintah untuk dijadikan pedoman dalam menerapkan kode etik dan melakukan penilaian risiko untuk mengendalikan lingkungan internal. Penerapan sistem pengendalian intern pemerintah meliputi lingkungan pengendalian (adanya kode etik dan pimpinan memberikan contoh baik dalam mengikuti kode etik), penilaian risiko (batas, toleransi, pengendalian intern, dan manajemen terhadap risiko), kegiatan pengendalian (otorisasi dan pemisahan tugas), informasi dan komunikasi (penerapan sistem informasi dalam pelaksanaan tanggung jawab yang memungkinkan audit), dan pemantauan oleh pimpinan. Dalam penelitian ini variabel penerapan sistem pengendalian intern pemerintah diukur menggunakan kuesioner yang 
mengacu pada penelitian Soimah dan Aprilla (2014). Indikator untuk variabel ini terdiri dari 9 buah pernyataan positif yaitu: 2 buah pernyataan mengenai lingkungan pengendalian, 2 buah pernyataan mengenai penilaian risiko, 2 buah pernyataan mengenai kegiatan pengendalian, 2 buah pernyataan mengenai informasi dan komunikasi, dan 1 buah pernyataan mengenai pemantauan. Variabel ini diukur dengan skala interval yaitu menggunakan skala Likert untuk 5 preferensi jawaban sebagai berikut: 1: Tidak Pernah (TP); 2: Jarang Sekali (JS); 3: Kadang-Kadang (KK); 4: Sering (S); 5: Sangat Sering (SS).

5. Sistem Akuntansi Keuangan Daerah

Sistem akuntansi keuangan daerah adalah serangkaian prosedur mulai dari proses pengumpulan data, pencatatan, pengikhtisaran, sampai dengan pelaporan keuangan dalam rangka pertanggungjawaban pelaksanaan anggaran pendapatan dan belanja daerah yang ditujukan untuk menghasilkan informasi berupa laporan keuangan yang dapat dilakukan secara manual atau menggunakan aplikasi komputer. Sistem akuntasi keuangan daerah dapat dilihat dari keamanan data, kecepatan akses, ketepatan waktu akses, ketelitian, variasi laporan yang dihasilkan, dan relevansi sistem dengan pengguna. Dalam penelitian ini variabel sistem akuntansi keuangan daerah diukur menggunakan kuesioner yang mengacu pada penelitian Dewi dan Mimba (2014). Indikator untuk variabel ini terdiri dari 14 pernyataan positif yang diukur dengan skala interval yaitu menggunakan skala Likert yang dijabarkan sebagai berikut:

a. 2 buah pernyataan keamanan data untuk 5 preferensi jawaban yaitu: 1: Sangat Tidak Aman (STA); 2: Tidak Aman (TA); 3: Kurang Aman (KA); 4: Aman (A); 5: Sangat Aman (SA).

b. 4 buah pernyataan kecepatan dan ketepatan waktu akses untuk 5 preferensi jawaban yaitu: 1: Sangat Lambat (SL); 2: Lambat (L); 3: Kurang Cepat (KC); 4: Cepat (C); 5: Sangat Cepat (SC). 
Pengaruh Penerapan Standar Akuntansi Pemerintah, Pemanfaatan Teknologi Informasi, Kompetensi Sumber Daya Manusia, Penerapan Sistem Pengendalian Intern Pemerintah, dan Sistem Akuntansi Keuangan Daerah Terhadap Kualitas Laporan Keuangan Pemerintah Daerah

c. 3 buah pernyataan ketelitian untuk 5 preferensi jawaban yaitu: 1: Sangat Tidak Teliti (STT); 2: Tidak Teliti (TT); 3: Kurang Teliti (KT); 4: Teliti (T); 5: Sangat Teliti (ST).

d. 1 buah pernyataan variasi laporan untuk 5 preferensi jawaban yaitu: 1: Sangat Tidak Variatif (STV); 2:

Tidak Variatif (TV); 3: Kurang Variatif (KV); 4: Variatif (V); 5: Sangat Variatif (SV).

e. 4 buah pernyataan relevansi/kesesuaian untuk 5 preferensi jawaban yaitu: 1: Sangat Tidak Relevan (STR); 2: Tidak Relevan (TR); 3: Kurang Relevan (KR); 4: Relevan (R); 5: Sangat Relevan (SR).

\subsection{Teknik Pengumpulan Data}

Pengumpulan data penelitian ini adalah dengan menggunakan data primer, yaitu data yang berasal langsung dari sumber asli atau pertama melalui instrumen yang disebut kuesioner yang diantarkan, dititipkan, atau dikirimkan kepada pegawai yang terlibat dalam penyusunan keuangan dan menggunakan sistem akuntansi keuangan daerah yaitu aplikasi Sistem Informasi Manajemen Daerah (SIMDA) di Satuan Kerja Perangkat Daerah (SKPD) di wilayah Tangerang. Penyebaran kuesioner dilakukan dengan cara mendatangi langsung SKPD yang diinginkan.

\subsection{Teknik Pengambilan Sampel}

Pada penelitian ini, terdapat 5 langkah dalam menentukan sampel yang harus dilakukan yaitu mendefinisikan populasi, menentukan kerangka sampel, menentukan teknik pengambilan sampel, menentukan besarnya sampel penelitian dan melaksanakan proses pengambilan sampel (Sekaran, 2016). Populasi yang digunakan dalam penelitian adalah pegawai pada Satuan Kerja Perangkat Daerah (SKPD) yang difasilitasi dengan komputer dan sistem akuntansi keuangan daerah. Sampel yang digunakan adalah pegawai pada SKPD wilayah Tangerang yang menggunakan sistem akuntansi keuangan daerah 
dan terlibat dalam penyusunan laporan keuangan. Cara pengambilan sampel adalah dengan menggunakan metode non probability sampling, yaitu bahwa setiap sampel tidak memiliki hak yang sama untuk terpilih, dan dengan teknik pengambilan sampel convenience sampling, yaitu memilih sampel berdasarkan kemudahan (Sekaran, 2016).

\subsection{Teknik Analisis Data}

Metode analisis data dalam penelitian ini menggunakan metode analisis statistik dengan bantuan SPSS 21 (Statistic Product \& Service Solution). Pengujian yang dilakukan dalam penelitian ini adalah pengujian data berupa uji statistik deskriptif,uji kualitas data, uji asumsi klasik (multikolonieritas, heteroskedastisitas), dan pengujian hipotesis.

\section{HASIL \& ANALISIS}

\subsection{Objek Penelitian}

Dalam penelitian ini, data yang diolah berupa jawaban responden atas kuesioner yang disebarkan ke kantor Satuan Kerja Perangkat Daerah (SKPD) di wilayah Kabupaten Tangerang yang difasilitasi dengan komputer dan sistem akuntansi keuangan daerah. Responden tersebut adalah pegawai pada SKPD wilayah Kabupaten Tangerang yang menggunakan sistem akuntansi keuangan daerah, dan terlibat langsung dalam penyusunan laporan keuangan, jumlah SKPD di wilayah Kabupaten Tangerang sebanyak 100 SKPD, tetapi penyebaran hanya dilakukan di dinas daerah yang berjumlah 23 dinas.

Penyebaran kuesioner dilakukan antara 2 Mei 2018 sampai 13 Mei 2018, sedangkan proses pengumpulan dilakukan sampai dengan 15 Mei 2018. Kuesioner disebarkan di SKPD wilayah Kabupaten Tangerang sejumlah 23 SKPD yang terdiri atas 23 kantor dinas. Berikut merupakan persentase jumlah kuesioner yang yang dikirim, kembali, tidak dapat digunakan, dan dapat digunakan: 
Pengaruh Penerapan Standar Akuntansi Pemerintah, Pemanfaatan Teknologi Informasi, Kompetensi Sumber Daya Manusia, Penerapan Sistem Pengendalian Intern Pemerintah, dan Sistem Akuntansi Keuangan Daerah Terhadap Kualitas Laporan Keuangan

Tabel 1. Sampel Penelitian dan Tingkat Pengembalian

\begin{tabular}{lcc}
\hline \multicolumn{1}{c}{ Uraian } & Jumlah & Persentase \\
\hline Kuesioner yang dikirim & 125 & $100 \%$ \\
Kuesioner yang kembali & 123 & $98.40 \%$ \\
Kuesioner yang tidak dapat digunakan & 12 & $9,75 \%$ \\
Kuesioner yang dapat digunakan & 111 & $90,25 \%$ \\
\hline
\end{tabular}

\subsection{Analisis dan Pembahasan}

\subsubsection{Statistik Deskriptif}

Statistik deskriptif memberikan gambaran atau deskripsi suatu data yang dilihat dari nilai rata-rata (mean), standar deviasi, maksimum, minimum, dan range. Berikut merupakan penghitungan statistik deskriptif untuk keenam variabel penelitian:

Tabel 2. Hasil Statistik Deskriptif

\begin{tabular}{ccccccc}
\hline & N & Range & Minimum & Maximum & Mean & $\begin{array}{c}\text { Std. } \\
\text { Deviation }\end{array}$ \\
\hline TOTALSAP & 111 & 40 & 95 & 135 & 114.73 & 10.339 \\
TOTALTI & 111 & 11 & 24 & 35 & 30.59 & 2.668 \\
TOTALSDM & 111 & 21 & 19 & 40 & 32.80 & 4.886 \\
TOTALSPIP & 111 & 17 & 28 & 45 & 37.57 & 3.716 \\
TOTALSAKD & 111 & 23 & 47 & 70 & 59.38 & 4.860 \\
TOTALLK & 111 & 21 & 34 & 55 & 46.86 & 4.408 \\
Valid N (listwise) & 111 & & & & & \\
\hline
\end{tabular}

Statistik deskriptif pada Tabel 2 menunjukkan bahwa jumlah responden $(\mathrm{N})$ sebanyak 111 orang. Untuk variabel kualitas laporan keuangan pemerintah daerah (LK), nilai terendah yang dimiliki responden (minimum) sebesar 34 dan nilai tertinggi (maksimum) sebesar 55. Nilai range dari 111 responden sebesar 21. Rata-rata jawaban (Mean) sebesar 46,84 dengan jumlah pernyataan sebanyak 11 buah, sehingga rata-rata jawaban untuk setiap pernyataan adalah sebesar 4,26 yang berarti rata-rata responden menjawab setuju bahwa laporan keuangan pemerintah daerah untuk wilayah Kabupaten Tangerang adalah laporan keuangan yang berkualitas dengan memenuhi karakteristik kualitatif yaitu relevan, andal, dapat dibandingkan, dan mudah dipahami. Adapun standar deviasi untuk kualitas laporan keuangan sebesar 4,408.

Pada variabel penerapan standar akuntansi pemerintahan (SAP), nilai terendah yang dimiliki responden 
(minimum) sebesar 95 dan nilai tertinggi (maksimum) sebesar 135. Nilai range dari 111 responden sebesar 40. Rata-rata jawaban (Mean) sebesar 114,73 dengan jumlah pernyataan sebanyak 27 buah, sehingga rata-rata jawaban untuk setiap pernyataan adalah sebesar 4,25 yang berarti rata-rata responden menjawab setuju bahwa SKPD di wilayah Kabupaten Tangerang telah menerapkan standar akuntansi pemerintah dalam menyusun laporan keuangan. Adapun standar deviasi untuk penerapan standar akuntansi pemerintahan sebesar 10,339.

Pada variabel pemanfaatan Teknologi Informasi (TI), nilai terendah yang dimiliki responden (minimum) sebesar 24 dan nilai tertinggi (maksimum) sebesar 35 . Nilai range dari 111 responden sebesar 11. Rata-rata jawaban (Mean) sebesar 30,59 dengan jumlah pernyataan sebanyak 7 buah, sehingga rata-rata jawaban untuk setiap pernyataan adalah sebesar 4,37 yang berarti rata-rata responden menjawab setuju bahwa dalam menyusun laporan keuangan pemerintah daerah wilayah
Kabupaten Tangerang telah menggunakan teknologi informasi. Adapun standar deviasi untuk pemanfaatan teknologi informasi sebesar 2,668.

Pada variabel kompetensi Sumber Daya Manusia (SDM), nilai terendah yang dimiliki responden (minimum) sebesar 19 dan nilai tertinggi (maksimum) sebesar 40. Nilai range dari 111 responden sebesar 21. Ratarata jawaban (Mean) sebesar 32,80 dengan jumlah pernyataan sebanyak 8 buah, sehingga rata-rata jawaban untuk setiap pernyataan adalah sebesar 4,10 yang berarti rata-rata responden menjawab setuju bahwa sumber daya manusia di wilayah Kabupaten Tangerang berkompeten dalam bidang akuntansi untuk menyusun laporan keuangan pemerintah daerah. Adapun standar deviasi untuk kompetensi sumber daya manusia sebesar 4,886.

Pada variabel Penerapan Sistem Pengendalian Intern Pemerintah (SPIP), nilai terendah yang dimiliki responden (minimum) sebesar 28 dan nilai tertinggi (maksimum) sebesar 45. Nilai range dari 111 responden sebesar 17. Rata-rata jawaban (Mean) sebesar 37,57 
Pengaruh Penerapan Standar Akuntansi Pemerintah, Pemanfaatan Teknologi Informasi, Kompetensi Sumber Daya Manusia, Penerapan Sistem Pengendalian Intern Pemerintah, dan Sistem Akuntansi Keuangan Daerah Terhadap Kualitas Laporan Keuangan

Pemerintah Daerah

dengan jumlah pernyataan sebanyak

9 buah, sehingga rata-rata jawaban untuk setiap pernyataan adalah sebesar 4,17 yang berarti rata-rata responden menjawab sering. Hal tersebut menunjukkan bahwa SKPD wilayah Kabupaten Tangerang telah menerapkan peraturan pemerintah nomor 60 tahun 2008 tentang sistem pengendalian intern pemerintah. Adapun standar deviasi untuk penerapan sistem pengendalian intern pemerintah sebesar 3,716.

Pada variabel Sistem Akuntansi Keuangan Daerah (SAKD), nilai terendah yang dimiliki responden (minimum) sebesar 47 dan nilai tertinggi (maksimum) sebesar 70 . Nilai range dari 111 responden sebesar 23. Rata-rata jawaban (Mean) sebesar 59,38 dengan jumlah pernyataan sebanyak 14 buah, sehingga rata-rata jawaban untuk setiap pernyataan adalah sebesar 4,24 yang berarti rata-rata responden menjawab setuju. Hal tersebut menunjukkan bahwa sistem akuntansi keuangan daerah pada SKPD wilayah Kabupaten Tangerang memiliki tingkat keamanan data yang cukup, cepat dan tepat dalam waktu akses, teliti dalam memproses data, laporan yang dihasilkan bervariasi, dan relevan dalam pengolahan data. Adapun standar deviasi untuk sistem akuntansi keuangan daerah sebesar 4,860 .

\subsubsection{Uji Validitas}

Uji validitas dilakukan untuk mengukur valid tidaknya suatu kuesioner. Uji validitas dilakukan dengan menggunakan Pearson Correlation. Berikut merupakan hasil uji validitas untuk keenam variabel:

Tabel 3. Hasil Uji Validitas

\begin{tabular}{lcc}
\hline \multicolumn{1}{c}{ Variabel } & Sig (2-tailed) & Keterangan \\
\hline Penerapan Standar Akuntansi & $0.000-0,004$ & Valid \\
Pemerintahan & 0.000 & Valid \\
Pemanfaatan Teknologi Informasi & 0.000 & Valid \\
Kompetensi Sumber Daya Manusia & 0.000 & Valid \\
Penerapan Sistem Pengendalian Intern & 0.000 & Valid \\
Pemerintah & $0.000-0.001$ & Valid \\
Sistem Akuntansi Keuangan Daerah & & \\
Kualitas Laporan Keuangan &
\end{tabular}


Dari hasil uji validitas yang dilakukan pada Tabel 3, variabel pemanfaatan teknologi informasi, penerapan sistem pengendalian intern pemerintah, sistem akuntansi keuangan daerah, dan kualitas laporan keuangan pemerintah daerah memiliki nilai sig $(2$ - tailed $)$ sebesar 0.000. Sedangkan penerapan standar akuntansi pemerintahan dan kompetensi sumber daya manusia memiliki nilai sig $(2$-tailed $)$ sebesar $0.000-0,004$. Hal ini menunjukkan bahwa semua pernyataan pada variabel penerapan standar akuntansi pemerintahan, pemanfaatan teknologi informasi, kompetensi sumber daya manusia, penerapan sistem pengendalian intern pemerintah, sistem akuntansi keuangan daerah dan kualitas laporan keuangan pemerintah daerah adalah valid, karena nilai sig (2 tailed) kurang dari 0,05.

\subsubsection{Uji Reliabilitas}

Uji reliabilitas dimaksudkan untuk menunjukkan sejauh mana pengukuran tersebut tanpa bias dan konsisten lintas waktu dan lintas beragam item dalam instrument. Uji reliabilitas dilakukan dengan menggunakan Cronbach's Alpha ( $\alpha)$. Berikut merupakan hasil uji reliabilitas untuk kelima variabel:

Tabel 4. Hasil Uji Reliabilitas

\begin{tabular}{lc}
\hline \multicolumn{1}{c}{ Variabel } & Cronbach's Alpha \\
\hline Penerapan Standar Akuntansi Pemerintahan &, 916 \\
Pemanfaatan Teknologi Informasi &, 741 \\
Kompetensi Sumber Daya Manusia &, 865 \\
Penerapan Sistem Pengendalian Intern &, 818 \\
Pemerintah &, 884 \\
Sistem Akuntansi Keuangan Daerah &, 777 \\
Kualitas Laporan Keuangan Pemerintah Daerah & \\
\hline
\end{tabular}

Berdasarkan hasil uji reliabilitas yang dilakukan didapatkan hasil Cronbach's Alpha untuk penerapan standar akuntansi pemerintahan, pemanfaatan teknologi informasi, kompetensi sumber daya manusia, penerapan sistem pengendalian intern pemerintah, sistem akuntansi keuangan daerah dan kualitas laporan keuangan pemerintah daerah memiliki nilai Cronbach's Alpha diatas 0.7. Maka seluruh variabel tersebut dapat dikatakan reliabel.

\subsubsection{Uji Normalitas}

Uji normalitas bertujuan untuk menguji apakah dalam model regresi 
Pengaruh Penerapan Standar Akuntansi Pemerintah, Pemanfaatan Teknologi Informasi, Kompetensi Sumber Daya Manusia, Penerapan Sistem Pengendalian Intern Pemerintah, dan Sistem Akuntansi Keuangan Daerah Terhadap Kualitas Laporan Keuangan Pemerintah Daerah

variabel pengganggu atau variabel residual memiliki distribusi data normal. Metode yang digunakan untuk pengujian normalitas adalah Kolmogorov-Smirnov Test. Berikut merupakan hasil uji normalitas:

Tabel 5. Hasil Uji Normalitas

\begin{tabular}{llr}
\hline \multicolumn{1}{c}{ Parameter } & $\begin{array}{r}\text { Unstandardized } \\
\text { Residual }\end{array}$ \\
\hline $\mathrm{N}$ & & 111 \\
Normal Parameters & Mean & .0000000 \\
& Std. Deviation & 2.49700802 \\
Most Extreme & Absolute & .119 \\
Differences & Positive & .089 \\
Kolmogorov-Smirnov Z & Negative & -.119 \\
Asymp. Sig. (2-tailed) & & 1.258 \\
a. Test distribution is Normal. & .084 \\
b. Calculated from data. &
\end{tabular}

Berdasarkan Tabel 5, dapat dilihat dari perhitungan one-sample Kolmogorov Smirnov $\quad Z$ menunjukkan hasil 1,258 dengan tingkat signifikansi sebesar 0,084, lebih besar dari 0,05. Variabel pengganggu atau residual terdistribusi normal karena hasil perhitungan one-sample Kolmogorov Smirnov menghasilkan nilai signifikansi lebih besar dari 0,05

\subsubsection{Uji Asumsi Klasik}

\section{Uji Multikolonieritas}

Uji multikolonieritas bertujuan untuk menguji apakah dalam model regresi ditemukan adanya korelasi antar variabel bebas (independen). Uji multikolonieritas dilakukan dengan melihat nilai Tolerance dan Variance Inflation Factor (VIF). Berikut merupakan hasil uji multikolonieritas:

Tabel 6. Hasil Uji Multikolonieritas

\begin{tabular}{clcr}
\hline & \multirow{2}{*}{ Model } & \multicolumn{2}{c}{ Collinearity Statistics } \\
& & & \\
\hline 1 & (Constant) & .321 & 3.116 \\
& TOTALSAP & .575 & 1.740 \\
& TOTALTI & .494 & 2.023 \\
& TOTALSDM & .305 & 3.275 \\
& TOTALSPIP & .401 & 2.495 \\
\hline & TOTALSAKD & &
\end{tabular}


Hasil dari uji multikolonieritas yang dilakukan menunjukkan bahwa semua variabel independen memiliki nilai tolerance diatas 0,1 dan nilai VIF dibawah 10. Hal tersebut menunjukkan bahwa tidak ada korelasi antara variabel independen, sehingga dapat dinyatakan bahwa pada model regresi tidak terjadi multikolonieritas antar variabel independen. Adapun variabel independen dalam penelitian ini adalah penerapan standar akuntansi pemerintahan, pemanfaatan teknologi informasi, kompetensi sumber daya manusia, penerapan sistem pengendalian intern pemerintah, sistem akuntansi keuangan daerah dan kualitas laporan keuangan pemerintah daerah

\section{Uji Heteroskedastisitas}

Uji heteroskedastisitas bertujuan untuk menguji apakah dalam model regresi terjadi ketidaksamaan variance dari residual dari satu pengamatan ke pengamatan lain. Uji heteroskedastisitas dilakukan dengan menggunakan grafik scatterplot. Berikut merupakan hasil uji heteroskedastisitas:

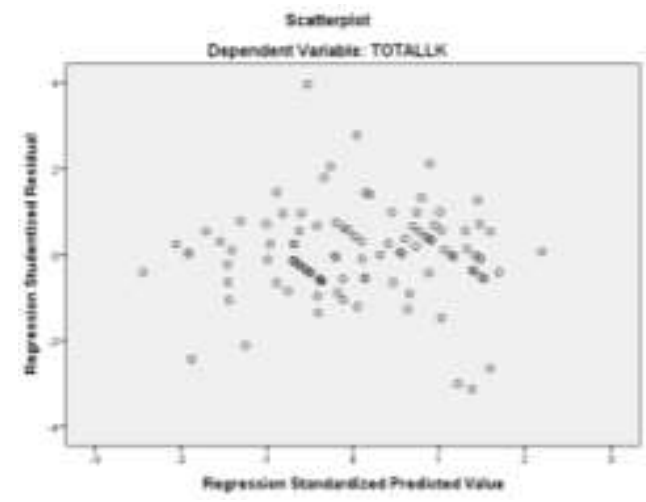

Gambar 2. Hasil Uji Heteroskedastisitas

Berdasarkan grafik scatterplot pada

Gambar 2, terlihat bahwa titik-titik tidak menghasilkan pola yang jelas (seperti bergelombang ataupun melebar kemudian menyempit) dan menyebar di atas dan di bawah angka 0 pada sumbu Y. Hal tersebut menunjukkan bahwa tidak terjadi heteroskedastisitas.

\subsubsection{Uji Hipotesis}

\section{Koefisien Determinasi}

Uji koefisien determinasi bertujuan untuk mengukur kemampuan model dalam menerangkan variasi variabel 
Pengaruh Penerapan Standar Akuntansi Pemerintah, Pemanfaatan Teknologi Informasi, Kompetensi Sumber Daya Manusia, Penerapan Sistem Pengendalian Intern Pemerintah, dan Sistem Akuntansi Keuangan Daerah Terhadap Kualitas Laporan Keuangan Pemerintah Daerah

dependen. Berikut merupakan hasil

uji koefisien determinasi:

Tabel 7. Hasil Pengujian Koefisien Determinasi

\begin{tabular}{lrrrr} 
& \multicolumn{4}{c}{ Model Summary $^{\mathrm{D}}$} \\
\hline Model & $\mathrm{R}$ & $\mathrm{R}$ & $\begin{array}{c}\text { Adjusted R } \\
\text { Square }\end{array}$ & Std. Error of the Estimate \\
\hline 1 &, $824^{\mathrm{a}}$ & Square & 679 & \multicolumn{2}{c}{, 664} & 2,556 \\
\hline
\end{tabular}

a. Predictors: (Constant), SAP, TI, SDM, SPIP, SAKD

b. Dependent Variable: LK

Dari hasil pengujian koefisien determinasi, nilai $\mathrm{R}$ dari model regresi sebesar 0,824, yang menunjukkan bahwa nilai $\mathrm{R}$ lebih besar dari 0,5. Hal tersebut menunjukkan bahwa variabel dependen yaitu kualitas laporan keuangan pemerintah daerah memiliki korelasi yang kuat dengan variabel independen penerapan standar akuntansi pemerintahan, pemanfaatan teknologi informasi, kompetensi sumber daya manusia, penerapan sistem pengendalian intern pemerintah, sistem akuntansi keuangan daerah. Nilai adjusted $R$ square sebesar 0,664. Hal tersebut menunjukkan bahwa $66,4 \%$ variabel kualitas laporan keuangan pemerintah daerah dijelaskan oleh kelima variabel independen yaitu variabel penerapan standar akuntansi pemerintahan, pemanfaatan teknologi informasi, kompetensi sumber daya manusia, penerapan sistem pengendalian intern pemerintah, sistem akuntansi keuangan daerah. Sedangkan sisanya sebesar 33,6\% dijelaskan oleh variabel lain diluar model penelitian.

\section{Uji Signifikansi Simultan (Uji Statistik F)}

Uji signifikansi simultan dilakukan untuk mengetahui apakah semua variabel independen yang dimasukkan kedalam model mempunyai pengaruh secara bersama-sama atau simultan terhadap variabel dependen. Berikut merupakan hasil uji signifikansi simultan: 
Tabel 8. Hasil Pengujian Signifikansi Simultan

ANOVA $^{\mathrm{a}}$

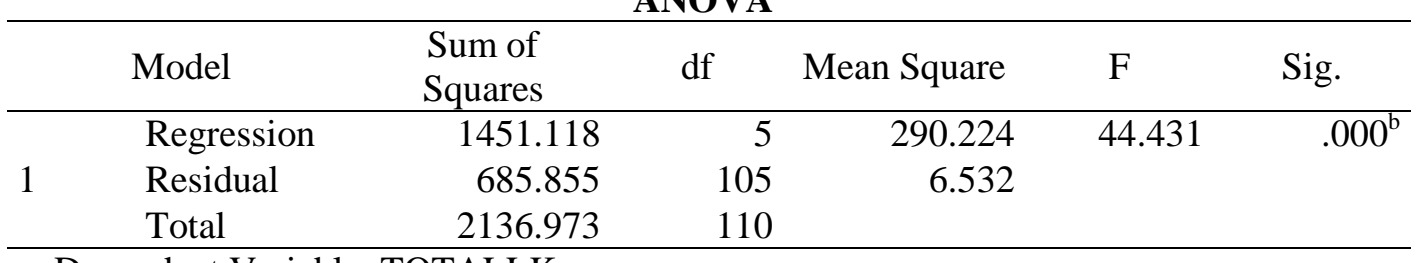

a. Dependent Variable: TOTALLK

b. Predictors: (Constant), TOTAL SAKD, TOTALTI, TOTALSDM, TOTALSAP, TOTALSPIP

Dari uji ANOVA atau $\mathrm{F}$, total didapat nilai $\mathrm{F}$ hitung sebesar 44,431 dengan tingkat signifikansi 0.000 . Karena tingkat signifikansi lebih kecil dari 0.05, maka model regresi dapat digunakan untuk memprediksi kualitas laporan keuangan pemerintah daerah, atau dapat dikatakan bahwa kelima variabel independen yaitu penerapan standar akuntansi pemerintahan, pemanfaatan teknologi informasi, kompetensi sumber daya manusia, penerapan sistem pengendalian intern pemerintah, sistem akuntansi keuangan daerah secara simultan berpengaruh signifikan terhadap kualitas laporan keuangan pemerintah daerah.

\subsection{Uji Signifikansi Parameter Individual (Uji Statistik t)}

Uji signifikansi parameter individual digunakan untuk menunjukkan seberapa jauh pengaruh variabel independen secara individual dalam menjelaskan variasi variabel dependen. Berikut merupakan hasil uji signifikansi parameter individual:

Tabel 9. Hasil Pengujian Signifikansi Parameter Invidual

\begin{tabular}{|c|c|c|c|c|c|c|}
\hline & \multirow[t]{2}{*}{ Model } & \multicolumn{2}{|c|}{$\begin{array}{l}\text { Unstandardized } \\
\text { Coefficients }\end{array}$} & \multirow{2}{*}{$\begin{array}{l}\text { Standardized } \\
\text { Coefficients } \\
\text { Beta }\end{array}$} & \multirow[t]{2}{*}{$\mathrm{t}$} & \multirow[t]{2}{*}{ Sig. } \\
\hline & & B & Std. Error & & & \\
\hline \multirow{6}{*}{1} & (Constant) & 6.379 & 3.392 & & 1.880 & .063 \\
\hline & TOTALSAP & .238 & .042 & .557 & 5.710 & .000 \\
\hline & TOTALTI & 436 & .120 & .264 & 3.622 & .000 \\
\hline & TOTALSDM & 168 & .071 & 187 & 2.375 & .019 \\
\hline & TOTALSPIP & .072 & .119 & .061 & 0.610 & .543 \\
\hline & TOTALSAKD & -.141 & .079 & -.155 & -1.779 & .078 \\
\hline
\end{tabular}

a. Dependent Variable: TOTALLK

$\begin{array}{llrrrr}\text { Berdasarkan } & \text { Tabel } & 9, & \text { variabel } & & \text { pemerintahan memiliki nilai statistik } \\ \text { penerapan } & \text { standar } & \text { akuntansi } & \mathrm{t} & \text { sebesar } & 5,710 \text { dengan tingkat }\end{array}$


Pengaruh Penerapan Standar Akuntansi Pemerintah, Pemanfaatan Teknologi Informasi, Kompetensi Sumber Daya Manusia, Penerapan Sistem Pengendalian Intern Pemerintah, dan Sistem Akuntansi Keuangan Daerah Terhadap Kualitas Laporan Keuangan Pemerintah Daerah

signifikansi sebesar 0,000 atau lebih kecil daripada 0,05. Hal ini menunjukkan $\mathrm{Ha}_{1}$ diterima, yang berarti penerapan standar akuntansi pemerintahan berpengaruh signifikan terhadap kualitas laporan keuangan pemerintah daerah. Penelitian ini sejalan dengan penelitian Dewi dan Mimba (2015) dan penelitian Evicahyani dan Setiawan (2016) yang menyatakan bahwa penerapan standar akuntansi pemerintahan berpengaruh signifikan terhadap kualitas laporan keuangan.

Variabel pemanfaatan teknologi informasi memiliki nilai statistik $\mathrm{t}$ sebesar 3,622 dengan tingkat signifikansi sebesar 0,000 atau lebih kecil daripada 0,05. Hal ini menunjukkan $\mathrm{Ha}_{2}$ diterima, yang berarti pemanfaatan teknologi informasi berpengaruh signifikan terhadap kualitas laporan keuangan pemerintah daerah.. Penelitian ini sejalan dengan penelitian Nurillah dan Muid (2014) yang menyatakan bahwa pemanfaatan teknologi informasi berpengaruh terhadap kualitas informasi laporan keuangan. Hasil penelitian ini sejalan dengan penelitian Yosefrinaldy (2013) yang menyatakan bahwa pemanfaatan teknologi informasi berpengaruh signifikan terhadap kualitas laporan keuangan.

Variabel kompetensi sumber daya manusia memiliki nilai statistik $\mathrm{t}$ sebesar 2,375 dengan tingkat signifikansi sebesar 0,019 atau lebih kecil daripada 0,05. Hal ini menunjukkan $\mathrm{Ha}_{3}$ diterima, yang berarti kompetensi sumber daya manusia berpengaruh signifikan terhadap kualitas laporan keuangan pemerintah daerah. Penelitian ini sejalan dengan penelitian Evicahyani dan Setiawan (2016) dan penelitian Subadriyah dan Rahayuningsih (2015) yang menyatakan bahwa kompetensi sumber daya manusia berpengaruh signifikan terhadap kualitas laporan keuangan.

Variabel penerapan sistem pengendalian intern pemerintah memiliki nilai statistik $\mathrm{t}$ sebesar 0,610 dengan tingkat signifikansi sebesar 0,543 atau lebih besar daripada 0,05. Hal ini menunjukkan $\mathrm{Ha}_{4}$ ditolak, yang berarti penerapan sistem pengendalian intern pemerintah tidak berpengaruh terhadap kualitas laporan keuangan 
pemerintah daerah. Sistem risiko kesalahan pencatatan pengendalian intern pemerintah yang diterapkan dengan baik akan meningkatkan keandalan laporan keuangan dengan mencegah terjadinya fraud dan mengurangi akuntansi pada laporan keuangan. Berikut adalah tabel jawaban responden antara penerapan sistem pengendalian intern pemerintah dan kualitas laporan keuangan.

Tabel 10. Jawaban Responden Penerapan Sistem Pengendalian Intern Pemerintah Dan Kualitas Laporan Keuangan

\begin{tabular}{lrr}
\hline \multicolumn{1}{c}{ LK $<4$} & Responden & Persentase \\
\hline SPIP $<4$ & 13 & $76,47 \%$ \\
SPIP 4 & 3 & $17,65 \%$ \\
SPIP $>4$ & 1 & $5,88 \%$ \\
Total & 17 & $100,00 \%$ \\
\hline & & \\
\hline \multicolumn{1}{c}{ LK $>4$} & Responden & Persentase \\
\hline SPIP $<4$ & 6 & $9,68 \%$ \\
SPIP 4 & 12 & $19,35 \%$ \\
SPIP $>4$ & 44 & $70,97 \%$ \\
Total & 62 & $100,00 \%$ \\
\hline & &
\end{tabular}

Dari 17 responden yang menjawab pernyataan kualitas laporan keuangan dengan nilai di bawah 4 $($ LK < 4) terdapat 4 atau $23,53 \%$ responden menjawab nilai penerapan sistem pengendalian intern pemerintah dengan nilai rata-rata lebih dari atau sama dengan 4. Dari 28 responden yang menjawab pernyataan kualitas laporan keuangan dengan nilai rata-rata 4 $(\mathrm{LK}=4)$ terdapat 5 atau $17,86 \%$ responden menjawab nilai penerapan sistem pengendalian intern pemerintah dengan nilai rata-rata di bawah 4 dan di atas 4. Dari 62

\begin{tabular}{lrr}
\hline \multicolumn{1}{c}{ LK $=4$} & Responden & Persentase \\
\hline SPIP $<4$ & 1 & $3,57 \%$ \\
SPIP 4 & 23 & $82,14 \%$ \\
SPIP $>4$ & 4 & $14,29 \%$ \\
Total & 28 & $100,00 \%$ \\
\hline & & \\
\hline LK $=5$ & Responden & Persentase \\
\hline SPIP $<5$ & 4 & $100,00 \%$ \\
SPIP $=5$ & 0 & $0,00 \%$ \\
& & \\
Total & 4 & $100,00 \%$ \\
\hline
\end{tabular}

responden yang menjawab pernyataan kualitas laporan keuangan pemerintah dengan nilai di atas $4(\mathrm{LK}>4)$, terdapat 18 atau $29,03 \%$ responden menjawab pernyataan penerapan sistem pengendalian intern pemerintah dengan nilai di bawah 4. Dari 4 responden yang menjawab pernyataan kualitas laporan keuangan dengan nilai $5(\mathrm{LK}=5)$, terdapat 4 atau $100 \%$ responden yang menjawab pernyataan penerapan sistem pengendalian intern pemerintah di bawah 5. Sehingga dari total 111 responden terdapat 31 
Pengaruh Penerapan Standar Akuntansi Pemerintah, Pemanfaatan Teknologi Informasi, Kompetensi Sumber Daya Manusia, Penerapan Sistem Pengendalian Intern Pemerintah, dan Sistem Akuntansi Keuangan Daerah Terhadap Kualitas Laporan Keuangan Pemerintah Daerah

atau $27,92 \%$ responden yang menjawab tidak konsisten pada penerapan sistem pengendalian intern pemerintah dan kualitas laporan keuangan, dan dari 31 responden tersebut terdapat 15 atau $48,38 \%$ responden bukan lulusan akuntansi. Secara keseluruhan terdapat 70 responden atau $63,06 \%$ yang bukan merupakan lulusan akuntansi. Dengan responden yang menjawab tidak konsisten dan kurang memahami akuntansi terhadap pernyataan tentang penerapan sistem pengendalian intern pemerintah dan kualitas laporan keuangan membuat variabel sistem pengendalian intern pemerintah menjadi tidak berpengaruh terhadap kualitas laporan keuangan. Penelitian ini sejalan dengan penelitian Setiyawati (2013) yang menyatakan bahwa penerapan sistem pengendalian intern tidak berpengaruh terhadap kualitas laporan keuangan. Hasil penelitian ini bertolak belakang dengan penelitian Evicahyani dan Setiawan (2016) yang menyatakan bahwa penerapan sistem pengendalian intern pemerintah berpengaruh signifikan terhadap kualitas laporan keuangan.

Variabel sistem akuntansi keuangan daerah memiliki nilai statistik $\mathrm{t}$ sebesar -1,796 dengan tingkat signifikansi sebesar 0,075 atau lebih dari 0,05 . Hal ini menunjukkan $\mathrm{Ha}_{5}$ ditolak, yang berarti sistem akuntansi keuangan daerah tidak berpengaruh terhadap kualitas laporan keuangan pemerintah daerah. Sistem akuntansi keuangan daerah dalam penelitian ini menggunakan aplikasi komputer yaitu Sistem Informasi Manajemen Daerah (SIMDA) yang diciptakan oleh Badan Pengawasan Keuangan dan Pembangunan (BPKP). Sistem informasi akuntansi yang efektif dapat memberikan keamanan dengan batasan - batasan akses, karena data hanya dapat diakses oleh pihak yang memiliki wewenang dan proses penyusunan laporan keuangan menjadi lebih teliti, sehingga akan meningkatkan keandalan laporan keuangan. Kecepatan akses yang dihasilkan membuat laporan keuangan disajikan tepat waktu (relevan). Dengan penyusunan yang sudah tersistematis dan terstruktur, laporan keuangan menjadi dapat 
dibandingkan dan mudah dipahami. Namun kecepatan dan ketepatan waktu akses dalam mencari, memproses dan mengolah data menjadi laporan oleh aplikasi SIMDA adalah kurang cepat di SKPD wilayah Kabupaten Tangerang. Hal tersebut dapat dilihat dari jawaban responden atas pernyataan mengenai kecepatan, ketepatan waktu akses dalam pencarian data dan dalam memproses, mengolah data, terdapat $16 \%$ responden yang menjawab dengan nilai dibawah 4. Hal tersebut menunjukkan bahwa rata-rata responden menjawab kurang cepat. Jika kecepatan dan ketepatan waktu akses dalam memproses dan mengolah data kurang akan menghambat pembuatan laporan keuangan sehingga mengakibatkan kurangnya relevansi suatu laporan keuangan. Tetapi sistem informasi dalam melakukan input dan menyajikan laporan keuangan tetap dalam kriteria cepat yang dapat dibuktikan dengan persentase jawaban responden tentang kecepatan dalam sistem input dan penyajian data dengan nilai diatas 3 adalah $92,8 \%$ membuat laporan keuangan tetap relevan sehingga kualitas laporan keuangan tetap terjaga Hasil penelitian ini bertolak belakang dengan penelitian Wati dkk, (2014) dan Subadriyah dan Rahayuningsih (2015) yang menyatakan bahwa sistem akuntansi keuangan daerah berpengaruh signifikan terhadap kualitas laporan keuangan.

\section{KESIMPULAN}

\subsection{Simpulan}

Berdasarkan hasil penelitian, dapat disimpulkan:

1. $\mathrm{Ha}_{1}$ diterima atau dapat diartikan penerapan standar akuntansi pemerintah berpengaruh signifikan terhadap kualitas laporan keuangan pemerintah daerah. Hal ini dapat dibuktikan dari nilai t sebesar 5,751 dengan tingkat signifikansi 0,000 atau lebih kecil dari 0,05. Hasil penelitian ini sejalan dengan hasil penelitian Dewi dan Mimba (2015) dan penelitian Evicahyani dan Setiawan (2016).

2. $\mathrm{Ha}_{2}$ diterima atau dapat diartikan pemanfaatan teknologi informasi berpengaruh signifikan terhadap 
Pengaruh Penerapan Standar Akuntansi Pemerintah, Pemanfaatan Teknologi Informasi, Kompetensi Sumber Daya Manusia, Penerapan Sistem Pengendalian Intern Pemerintah, dan Sistem Akuntansi Keuangan Daerah Terhadap Kualitas Laporan Keuangan Pemerintah Daerah

kualitas laporan keuangan pemerintah daerah. Hal ini dibuktikan dari nilai $\mathrm{t}$ sebesar 3,644 dengan tingkat signifikansi 0,000 atau lebih kecil dari 0,05. Hasil penelitian ini sejalan dengan hasil penelitian Nurillah dan Muid (2015), dan penelitian Yosefrinaldy (2013).

3. $\mathrm{Ha}_{3}$ diterima atau dapat diartikan kompetensi sumber daya manusia berpengaruh signifikan terhadap kualitas laporan keuangan pemerintah daerah. Hal ini dibuktikan dari nilai $\mathrm{t}$ sebesar 2,389 dengan tingkat signifikansi sebesar 0,019 atau lebih kecil dari 0,05. Hasil penelitian ini sejalan dengan hasil penelitian Evicahyani dan Setiawan (2016), dan penelitian Subadriyah dan Rahayuningsih (2015).

4. $\mathrm{Ha}_{4}$ ditolak atau dapat diartikan sistem pengedalian intern pemerintah tidak berpengaruh signifikan terhadap kualitas laporan keuangan pemerintah daerah. Hal ini dapat dibuktikan dari nilai t sebesar 0,616 dengan tingkat signifikansi sebesar 0,539 atau lebih besar dari 0,05. Hasil penelitian ini sejalan dengan hasil penelitian setiyawati (2013), penelitian ini bertolak belakang dengan penilitian Evicahyani dan Setiawan (2016).

5. $\mathrm{Ha}_{5}$ ditolak atau dapat diartikan sistem akuntansi keuangan daerah tidak berpengaruh terhadap kualitas laporan keuangan pemerintah daerah. Hal ini dapat dibuktikan dari nilai $\mathrm{t}$ sebesar -1,796 dengan tingkat signifikansi sebesar 0,075 atau lebih besar dari 0,05. Hasil penelitian ini bertolak belakang dengan penelitian Wati Dkk, (2014) dan penelitian Subadriyah dan Rahayuningsih (2015).

6. Penerapan standar akuntansi pemerintah, pemanfaatan teknologi informasi, kompetensi sumber daya manusia, penerapan sistem pengendalian intern pemerintah, dan sistem akuntansi keuangan daerah secara simultan berpengaruh signifikan terhadap kualitas 
laporan keuangan pemerintah daerah. Hasil penelitian ini sejalan dengan penelitian Ahsani (2016), dan Wati dkk (2014).

\subsection{Keterbatasan}

Keterbatasan dalam penelitian ini adalah :

1. Sampel penelitian terbatas pada Satuan Kerja Perangkat Daerah (SKPD) wilayah Kabupaten Tangerang, sehingga tidak dapat digeneralisasi untuk seluruh kantor pemerintahan di Jabodetabek.

2. Berdasarkan nilai adjusted $R$ square pada uji koefisien determinasi, variabel independent yang digunakan pada penelitian ini mampu menjelaskan sebesar $66,4 \%$ terhadap kualitas laporan keuangan pemerintah daerah, sedangkan $33,6 \%$ dijelaskan oleh variabel di luar model penelitian ini.

\subsection{Saran Dan Implikasi}

\subsubsection{Saran}

1. Bagi kantor SKPD

a. Melakukan peningkatan terhadap pengendalian internal pada Satuan Kerja Perangkat Daerah (SKPD) untuk mengurangi tingginya risiko terhadap kualitas laporan keuangan.

b. Melakukan peningkatan dan perawatan terhadap sistem akuntansi keuangan daerah agar kecepatan dan ketepatan waktu akses tetap terjaga sehingga relevansi laporan keuangan juga tetap terjaga.

2. Bagi peneliti selanjutnya

a. Melakukan pendistribusian kuesioner mencakup ruang lingkup yang lebih luas dan tersebar. Pendistribusian dapat dilakukan di seluruh Satuan Kerja Perangkat Daerah (SKPD) Jabodetabek.

b. Menggunakan atau menambahkan variabel independen lain yang dapat mempengaruhi kualitas laporan keuangan yang tidak digunakan dalam penelitian ini. Contoh variabel independen yang dapat ditambahkan pada penelitian selanjutnya yaitu: komitmen manajer. 
Pengaruh Penerapan Standar Akuntansi Pemerintah, Pemanfaatan Teknologi Informasi, Kompetensi Sumber Daya Manusia, Penerapan Sistem Pengendalian Intern Pemerintah, dan Sistem Akuntansi Keuangan Daerah Terhadap Kualitas Laporan Keuangan

Pemerintah Daerah

\subsubsection{Implikasi}

Pihak yang berwenang atau kepala sub-bagian akuntansi harus tetap menjaga penerapan standar akuntansi pemerintahan dalam menyajikan laporan keuangan. Melakukan perawatan yang teratur terhadap teknologi informasi yang digunakan, yaitu komputer dan internet. Karyawan dalam kantor SKPD perlu mendapatkan pelatihan yang cukup dalam menyajikan laporan keuangan dan juga dalam melakukan perekrutan karyawan, calon pegawai negeri sipil harus dipilih seusai dengan keahlian yang dimilikinya.

\section{DAFTAR PUSTAKA}

Adhi, Daniel Kartika dan Yohanes Suhardjo. 2013. "Pengaruh Penerapan Standar Akuntansi Pemerintah dan Kualitas Aparatur Pemerintah Daerah Terhadap Kualitas Laporan Keuangan" (Studi Kasus Pada Pemerintah Kota Tual). Jurnal STIE Semarang Vol.5, No.3. Semarang: STIE AKA.

Agoes, Sukrisno dan I Centik Ardana, 2014. Etika Bisnis Dan Profesi (Tantangan Membangun Manusia Seutuhnya). Jakarta: Salemba Empat

Arif, Bahtiar, Muchlis, dan Iskandar. 2009. Akuntansi Pemerintahan. Jakarta: Akademia.
Almasri, M. $\quad$ Nazar. 2016. "Manajemen Sumber Daya Manusia: Imlementasi Dalam Pendidikan Islam" e-Jurnal Vol. 19, No. 2. Jakarta: Universitas Islam Negeri.

Delanno, Galuh Fajar Dan Deviani. 2013. "Pengaruh Kapasitas SDM, Pemanfaatan TI, Dan Pengawasan Keuangan Terhadap Nilai Informasi Pelaporan Keuangan Pemerintah Daerah". e-Jurnal Akuntansi Vol. 1, No. 1 Padang: Universitas Negeri Padang

Dewi, Ayu Ratna dan Ni Putu Sri Harta Mimba. 2014. "Pengaruh Efektivitas Penerapan Sistem Informasi Pengelolaan Keuangan Daerah (SIPKD) terhadap Kualitas Laporan Keuangan". e-Jurnal Akuntansi Universitas Udayana, Denpasar: Udayana.

Evicahyani, Sagung Inten dan Nyoman Djinar Setiawan. 2016. "Analisis Faktor Faktor yang Mempengaruhi Kualitas Laporan Keuangan Pemerintah Daerah Kabupaten Tabanan". e-Jurnal Ekonomi dan Bisnis Udayana, Denpasar: Udayana.

Ghozali, Imam. 2016. Aplikasi Analisis Multivariate dengan Program IBM SPSS 23. Semarang: Badan Penerbit Universitas Diponegoro. 
Hadiputro, Eliza Kusumawardani dan Evi Octavia, 2015." Pengaruh Kompetensi Sumber Daya Manusia Dan Penerapan Sistem Akuntansi Instansi Terhadap Kualitas Laporan Keuangan (Survei padaBadan Geologi, Kementerian Energi Sumber Daya Mineral). Jurnal Universitas Widyatama

Herawati, Tuti. 2014. "Pengaruh Sistem Pengendalian Intern terhadap Kualitas Laporan Keuangan (Survey Pada Organisasi Perangkat Daerah Pemda Cianjur)". Star-Study \& Accounting Research, Bandung: STIE STEMBI.

Ichlas, Muhammad, Dr. Hasan Basri.

M.Com, Ak, dan Dr. Muhammad Arfan. SE, M.Si, Ak, CA. 2014. "Pengaruh Penerapan Standar Akuntansi Pemerintah, Sistem Pengendalian Intern Pemerintah Dan Aksesibilitas Laporan Keuangan Terhadap Akuntabilitas Keuangan Pemerintah Kota Banda Aceh". Jurnal Magister Akuntansi Vol.3, No.4 Banda Aceh: Universitas Syiah Kuala

John, M. Yusuf dan Dwi Setiawan. 2009. Kiat Memahami Pemeriksaan Laporan Keuangan Pemerintah daerah di Indonesia. Jakarta: PT Gramedia Pustaka Utama.
Juwita, Rukmi. 2013. "Pengaruh Implementasi Standar Akuntansi Pemerintah dan Sistem Informasi Akuntansi terhadap Kualitas Laporan Keuangan”. Jurnal Trikonomika Vol.12, No.2. Bandung: Trikonomika.

Mahmudi. 2013. Akuntansi Sektor Publik. Yogyakarta: UII Press Yogyakarta.

Muzahid, Mukhlisul. 2014. "Pengaruh Tingkat Pendidikan, Kualitas Pelatihan, dan Lama Pengalaman Kerja Pegawai terhadap Kualitas Laporan Keuangan Satuan Kerja Perangkat Daerah (SKPD)". Jurnal Akuntansi Vol.2, No.2. Lhokseumawe: Politeknik Negri Lhokseumawe.

Nugraha, Harmadhani Adi dan Yuli Widi Astuti. 2013. "Analisis Penerapan Sistem Informasi Manajemen Keuangan Daerah (SIMDA KEUANGAN) Dalam Pengolahan Data Keuangan Pada Organisasi Pemerintah Daerah. Jurnal Akuntansi Aktual Vol. 2, No. 1. Malang: Universitas Negeri Malang

Nordiawan, Deddi dan Ayuningtyas Hertianti. 2010. Akuntansi Sektor Publik. Jakarta : Salemba Empat 
Pengaruh Penerapan Standar Akuntansi Pemerintah, Pemanfaatan Teknologi Informasi, Kompetensi Sumber Daya Manusia, Penerapan Sistem Pengendalian Intern Pemerintah, dan Sistem Akuntansi Keuangan Daerah Terhadap Kualitas Laporan Keuangan Pemerintah Daerah

Nurillah, As Syifa dan Dul Muid, 2014. " Pengaruh Kompetensi Sumber Daya Manusia, Penerapan Sistem Akuntansi Keuangan daerah (SAKD), Pemanfaatan Teknologi Informasi, Dan Sistem Pengendalian Intern Terhadap Kualitas Laporan Keuangan Pemerintah Daerah (Studi Empiris Pada SKPD Kota Depok)". Journal Of Accounting Vol.3, No.2. Semarang : Universitas Dipenogoro

Nurlaila, 2014. “ Pengaruh Efektivitas Penerapan Standar Akuntansi Pemerintahan Terhadap Kualitas Laporan Keuangan Pemerintah Daerah (Studi Pada Pemerintah Kabupaten Enrekang)".

Pujanira, Putriasri dan Abdullah Taman. 2017. "Pengaruh Kompetensi Sumber Daya Manusia , Penerapan Standar Akuntansi Pemerintahan, Dan Penerapan Sistem Akuntansi Keuangan Daerah Terhadap Kualitas Laporan Keuangan Pemerintah Daerah". Jurnal Akuntansi Vol. 6, No. 2 Yogyakarta: Universitas Negeri Yogyakarta

Republik Indonesia. Peraturan Kepala Badan Kepegawaian Negara Nomor 23 Tahun 2011 tentang Pedoman Penilaian Kompetensi Pegawai Negri Sipil.
Republik Indonesia. Peraturan Menteri Negara Pendayagunaan Aparatur Sipil Negara Nomor 21 Tahun 2008 tentang Pedoman Penyususnan Standard Operating Procedures (SOP) Administrasi Pemerintahan.

Republik Indonesia. Peraturan Pemerintah Nomor 56 Tahun 2005 tentang Sistem Informasi Keuangan Daerah.

Republik Indonesia. Peraturan Pemerintah Nomor 41 Tahun 2007 tentang Organisasi Perangkat Daerah.

Republik Indonesia. Peraturan Pemerintah Nomor 60 Tahun 2008 tentang Sistem Pengendalian Intern Pemerintah.

Republik Indonesia. Peraturan Pemerintah Nomor 82 Tahun 2012 tentang Penyelenggaraan Sistem dan Transaksi Elektronik.

Republik Indonesia. UndangUndang Nomor 17 Tahun 2003 tentang Keuangan Negara.

Republik Indonesia. UndangUndang Nomor 36 Tahun 1999 tentang Telekomunikasi.

Republik Indonesia. Undang-Undang Nomor 15 Tahun 2004 tentang Pemeriksaan Pengelolaan dan Tanggung Jawab Keuangan Negara. 
Republik Indonesia. Undang-undang Nomor 5 Tahun 2014 tentang Aparatur Sipil Negara.

Republik Indonesia. 2013. Standar Akuntansi Pemerintahan: Peraturan Pemerintah Nomor 71 Tahun 2010.

Republik Indonesia. Peraturan Pemerintah Dalam Negeri Nomor 13 Tahun 2006 tentang Pedoman Pengelolaan Keuangan Daerah.

Sekaran, Uma dan Roger Bougie.2016. Research Methods for Business: A SkillBuilding Approach, 7th Edition. Inggris : Wiley

Setiyawati, Hari. 2013. "The Effect of Internal Accountants, Competence, Managers' Commitment to Organization and The Implementation of the Internal Control System on Quality of Financial Reporting”. International Journal of Business and Management Invention Vol.2, No.11.

Subadriyah dan
Rahayuningsih. Anita
"Analisis Hubungan Kualitas
Sumber Daya Manusia dan
Kualitas Sistem Akuntansi
Keuangan Daerah dengan
Kualitas Laporan Keuangan
Pemerintah Daerah". The 2 $2^{\text {nd }}$
University Research Coloqium.
Jepara: Universitas Islam
Nahdiatul Utama

Sudiarianti, Ni Made, I Gusti Ketut Agung Ulupui, dan I G.A. Budiasih. 2015. "Pengaruh Kompetensi Sumber Daya Manusia Pada Penerapan Sistem Pengendalian Intern Pemerintah Dan Standar Akutansi Pemerintah Serta Implikasinya Pada Kualitas Laporan Keuangan Pemerintah Daerah". Universitas Udayana (Unud), Bali, Indonesia.

Sutrisno, Edy. 2010. Manajemen Sumber Daya Manusia, Edisi Kedua. Jakarta: Perdana Media Group.

Suwita, Monika Khairunnisa dan Sendi Gusnandar Arnan, 2015. " Pengaruh Penerapan Standar Akuntansi Pemerintahan Terhadap Kualitas Laporan Keuangan Pemerintah Daerah (Studi Kasus pada Dinas Keuangan Daerah Kabupaten Indramayu)". Jurnal Universitas Widyatama Vol.1, No.2.

Soimah, Siti, 2014. “ Pengaruh Kapasitas Sumber Manusia, Pemanfaatan Teknologi Informasi, Dan Sistem Pengendalian Intern Pemerintah Terhadap Kualitas Laporan Keuangan Pemerintah Daerah Kabupaten Bengkulu Utara".

Utama, Arif Budhi, 2015. “ Pemanfaatan Teknologi Informasi Di Kalangan Mahasiswa Universitas Negeri Surabaya". Vol. 4, No. 3. Surabaya: Universitas Airlangga Surabaya 
Pengaruh Penerapan Standar Akuntansi Pemerintah, Pemanfaatan Teknologi Informasi, Kompetensi Sumber Daya Manusia, Penerapan Sistem Pengendalian Intern Pemerintah, dan Sistem Akuntansi Keuangan Daerah Terhadap Kualitas Laporan Keuangan Pemerintah Daerah

Yensi, Desy Sefry, Amir Hasan dan Yuneita Anisma. 2014. "Pengaruh Kompetensi Sumber Daya Manusia, Penerapan Sistem Akuntansi Keuangan Daerah, Dan Sistem Pengendalian Intern (Internal Audit) Terhadap Kualitas Laporan Keuangan Pemerintah Daerah". Jurnal Akuntansi Vol.1, No. 2. Pekanbaru: Universitas Riau

Yosefrinaldi. 2013. "Pengaruh Kapasitas Sumber Daya Manusia dan Pemanfaatan Teknologi Informasi Terhadap Kualitas Laporan Keuangan Pemerintah Daerah dengan Variabel Intervening Sistem Pengendalian Intern Pemerintah" (Studi Empiris pada Dinas Pengelolaan Keuangan dan Aset Daerah SeSumatera Barat). Jurnal Program Studi Akuntansi Fakultas Ekonomi. Sumatra: Universitas Negeri Padang.

Wati, Kadek Desiana, Nyoman Trisna Herawati, dan Ni Kadek Sinarwati. 2014. "Pengaruh Kompetensi SDM, Penerapan SAP, Dan Sistem Akuntansi Keuangan Daerah Terhadap Kualitas Laporan Keuangan Daerah. e-Jurnal Akuntansi Vol. 2, No. 1 Singaraja: Universitas Pendidikan Ganesha

www.tangerangkota.go.id Diakses 13 Maret 2017.

www.kemenkeu.go.id 7 Maret 2017

www.bpk.go.id Diakses 20 September 2017

http://dprd.batangharikab.go.id/artike 1-18-mewujudkan-standarakuntansi-pemerintah-berbasisakrual.html. Diakses 27 Maret 2018

http://www.bpk.go.id/assets/files/ihp s/2017///ihps_i_2017_1507002 855.pdf. Diakses 27 Maret 2018

https://www.djpbn.kemenkeu.go.id/p ortal/id/datapublikasi/kamus/kamusspan/2052-skpd-satuan-kerjaperangkat-daerah.html.

Diakses 20 September 2018

https://tangerangkab.go.id/tangerang kab-web/files/PERDA\%20152014\%20OPD1\%20_Lampiran \%20I_.pdf. Diakses 20 September 2018

http://www.bpkp.go.id/sakd/konten/3 33/Versi-2.1.bpkp. Diakses 21 September 2018 